DE SYSTEMATIEK DER JAVAANSE PRONOMINA 
E.M. Uhlenbeck - 978-90-04-28654-2 Downloaded from Brill. come4/26/2023 09:56:05AM via free access 


\title{
VERHANIDLLINGEI
}

VAN HET KONINKLIJK INSTITUUT VOOR TAAL-, LAND- EN VOLKENKUNDE

\author{
DEEL XXX
}

\section{DE SYSTEMATIEK \\ DER JAVAANSE PRONOMINA \\ DOOR}

E. M. UHLENBECK

'S.GRAVENHAGE-MARTINUS NIJHOFF-1960 
E.M. Uhlenbeck - 978-90-04-28654-2 Downloaded from Brill. come4/26/2023 09:56:05AM via free access 


\section{INHOUD}

blz.

VOORWOORD . . . . . . . . . . . . . . . . . . VI

LIJST VAN AFKORTINGEN . . . . . . . . . . . . . . . VII

1. INLEIDING . . . . . . . . . . . . . . . . . . . . . . 1

2. ALGEMEen OVERZicht . . . . . . . . . . . . . . . . . 3

3. PRONOMINA PERSONALIA. . . . . . . . . . . . . . . 5

4. PRONOMINA DEMONSTRATIVA . . . . . . . . . . . 15

1. Algemene karakteristiek . . . . . . . . . . . 15

2. De $i k i$-serie . . . . . . . . . . . . . . . 16

3. De kene-serie . . . . . . . . . . . . . . . 31

4. De mĕṅkene-serie . . . . . . . . . . . . . 35

5. De mrene-serie . . . . . . . . . . . . . . . 41

6. De sĕmene-serie . . . . . . . . . . . . . 44

7. De sĕprene-serie . . . . . . . . . . . . . 47

8. Samenvatting . . . . . . . . . . . . 49

5. PRONOMINA INTERROGATIVA ET INDEFINITA . . . . . . . . 50

1. De categorieën . . . . . . . . . . . . 50

2. Afkortingen, transpositiemogelijkheden en verdere bijzonderheden . . . . . . . . . . . 55

A. Sapa . . . . . . . . . . . . . . . 55

B. $A p a$. . . . . . . . . . . . . . . 56

c. Endi. . . . . . . . . . . . . . . 60

D. Kĕpriye . . . . . . . . . . . . . . 61

E. Pira . . . . . . . . . . . 63

F. Kapan . . . . . . . . . . . . . . 63 


\section{VOORWOORD}

Het is wellicht niet overbodig om met enkele woorden het kader aan te geven waarin deze studie moet worden geplaatst. $Z_{\mathrm{ij}}$ vormt een onderdeel van een zo volledig mogelijke beschrijving van het Standaard-Javaans. $\mathrm{Na}$ de beschrijving van klankstelsel en morfonologie in 1949 houdt mij thans vooral de morfologie bezig, waarvan ik de laatste jaren verschillende hoofdstukken heb behandeld. Met de descriptie van de pronomina is wederom een hoofdstuk voltooid. Het is mijn voornemen om nadat wat thans nog resteert in monografieën is besproken, de syntaxis aan de beurt te laten komen. Wat ik nl. hierover in 1941 in mijn beknopte Javaanse Grammatica schreef, acht $\mathrm{ik}$ thans volledig verouderd. Bij deze pogingen tot minutieuze descriptie word ik geleid door het besef, dat gedetailleerde en zo nauwkeurig mogelijke beschrijvingen van zgn. exotische talen tot de verdere ontwikkeling van de taalkunde een belangrijke bijdrage kunnen leveren. Descriptieve studies die berusten op slechts enkele weken of maanden fieldwork door een linguist die de taal in kwestie niet als taalgebruiker weet te hanteren, mogen nuttig zijn als eerste exploratie, zij kunnen echter gevaarlijk worden wanneer men in de illusie verkeert, dat op basis daarvan de taalwetenschap verder uit te bouwen is.

Deze studie zou ik niet hebben kunnen schrijven, als ik niet de geduldige en belangstellende steun had gehad van mijn informanten de heren R. Slamet Roosman en R. Soejono en bovenal van mijn assistent de heer J. Soegiarto. Allen breng ik hierbij dank. 


\section{LIJST VAN AFKORTINGEN}

AMK R. Hardjawiraga en M. Koesrin, Ajo menjang kolonisasi, 1940.

AW M. Soeradi, Anteping wanita, B.P. sr no. 864, 1929.

BD G. W. J. Drewes, Eenvoudig hedendaagsch Javaansch proza, Leiden 1946.

BG M. Soeratman Sastradiardja, Botjah ing goenoeng, B.P. sr no. 853 en 853a, 1929.

BS „Petroek”, Bojong njang sabrang, B.P. sr no. 1320, 1938.

DjP Rm. Ng. Sri Hadiwidjojo, Djoḍo kang pinasți, B.P. sr no. 1882, 1952.

ER Ekonomi Rajat, ed. Bale Pustaka, jaargang 1940.

GW Koescemadigda, Gawaning wewatekan, B.P. sr no. 788 en 788a, 1928.

K Kadjawèn, ed. Bale Pustaka, jaargang 1940.

KA M. Soeratman Sastradiardja, Kantja anjar, B.P. sr no. 805, 1928.

LBK Kamsa Wirjasaksana, Lelakone botjah kampoeng, B.P. sr no. 733, 1926.

MMTj Mw. Asmawinangoen, Moengsoeh moengging tjangklakan, B.P. sr no. 824 en $824 a, 1929$.

OA Th. Suroto, O, anakku...!, B.P. sr no. 1874, 1952.

OOA „Bakti”, Ontjèn-ontjèn anjar, 1949.

OP R. Soemantri Hardjadibrata, Obrolipoen Pétroek, B.P. sr no. 1422a, 1941.

PPB (M. Koesrin), Piet-Pon-Blès, B.P. sr no. 1327, 1939.

PPT Mw. Asmawinangoen, Pepisahan pitoelikoer taoen, B.P. sr no. 870 en $870 a, 1929$.

RS M. Kamit Nataasmara, Rasa-Sasmita, B.P. sr no. 992, 1932.

SB M. Mardjana lan M. Samoed Sastrowardojo, Sinau Basa, 1952.

SDS Mas Soetardja, Serat Dora Sembada, B.P. sr no. 233, 1917.

$\mathrm{Sg}$ J. Soegiarto, een informant.

$\mathrm{Sj} \quad$ R. Soejono, een informant.

SK R. Hardjawiraga, Sri Kuning, B.P. sr no. 1933, 1953. 
Skt $\quad$ M. S. Sastradiardja, Soekatja, B.P. sr no. 519, 1923.

SIR R. Slamet Roosman, een informant.

SPM Mw. Asmawinangoen, Saking papa doemoegi moelja, B.P. sr no. 782 en 782a, 1928.

SR R. B. Soelardi, Serat Rijanta, B.P. sr no. 432, 1920.

SrK L. K. Djajasoekarsa, Sri Koemenjar, B.P. sr no. 1286, 1938.

SS Kamsa, Soepraba lan Soeminten, B.P. sr no. 636, 1923.

SW Sastradiardja, Soewarsa-Warsijah, B.P. sr no. 756, 1926.

TB Taman Botjah, ed. Bale Pustaka, jaargang 1940.

$\mathrm{TjB} \quad$ Mas Samoed Sastrawardaja, Tjampoer Bawoer, 1949.

WG Soeradi Wirjaharsana, Wisaning agesang, B.P. sr no. 803, 1928. 


\section{INLEIDING}

In de bestaande Javaanse spraakkunsten berust de beschrijving van de pronomina op een in vele opzichten onvolledige analyse van het taalgebruik, terwijl er ook theoretische tekortkomingen in de behandelingswijze zijn. Dit baart geen verwondering als men in aanmerking neemt, dat de laatste omvangrijke Javaanse spraakkunst, die van Kiliaan, nu veertig jaar oud is. Er zijn geen afzonderlijke studies aan de Javaanse pronomina gewijd. Het heeft dan ook weinig zin om critisch in te gaan op wat in vroegere werken over de pronomina is opgemerkt.

Een descriptie van een woordsoort omvat in het algemeen het beschrijven naar vorm, betekenis en valentie van de categoriale relaties die tussen bepaalde groepen woorden bestaan en tevens van de transpositie-verschijnselen naar en van andere woordsoorten, die zich incidenteel of regelmatig voordoen. De pronomina behoren voor zover bekend, in alle talen tot de zgn. gesloten woordsoorten; hun aantal is aftelbaar; uitbreiding van het stelsel komt moeilijk tot stand. Of er een algemene tendentie tot vereenvoudiging bestaat naar Frei meent ${ }^{1}$, is mogelijk, maar nog niet bewezen. Fundamenteel is verder voor de pronomina, dat zij semantisch slechts gedefiniëerd kunnen worden in verband met ,the speechevent” en ,the participants of the speechevent". 2

De theoretische uitgangspunten van het onderzoek zijn sinds mijn algemene artikel over de woordsoorten van 19533 in wezen niet veranderd. Wel zijn ze op verschillende punten uitgewerkt. Ik kan daarom volstaan met te verwijzen naar vroegere publicaties. ${ }^{4}$ De daarin

1 Henri Frei, Systèmes de deictiques, Acta Linguistica 4 (1944), p. 111-129.

2 Roman Jakobson, Shifters, verbal categories, and the Russian verb, 1957.

3 The study of wordclasses in Javanese, Lingua III, 3, p. 322-354.

4 Woordverdubbeling in het Javaans, BKI 109, 1 (1953), p. 55-61; De systematiek der Javaanse telwoorden, id. 109, 4 (1953), p. 342-375; Verdubbelingsprocédé's bij het Javaanse werkwoord, id. 110, 4 (1954), p. 369-387; Over woordvorming in het Javaans, id. 111, 3 (1955), p. 286-307; Verb structure in Javanese, For Roman Jakobson, 1956, p. 567-573; Die mit javanisch rasa morphologisch zusammenhängenden Wörter, Oriens extremus 6 (1959), p. $104-115$.

Verh. dl. XXX 
gebruikte terminologie wordt ook nu weer gehanteerd, met dien verstande dat de term betekenis alleen nog gebruikt wordt met betrekking tot het woord, de term inhoud alleen met betrekking tot de zin. Bij de semantische beschrijving van de categoriale woordmomenten gebruik ik thans, na overleg met Reichling, de term waarde. Deze uitbreiding van de terminologie is voortgekomen uit het inzicht dat het niet aangaat de term betekenis gelijkelijk toe te passen op zulke uiteenlopende semantische grootheden als de semantische eenheid ad hoc die de zin is, de relatief-zelfstandige betekeniseenheid van het woord en het aan deze eenheid gesubordineerde onzelfstandige categoriale moment, dat c.q. in deze eenheid optreedt. Verdergaande analyse van de semantische verschijnselen vraagt onherroepelijk om differentiatie van de terminologie. Met de term betekenis kan men niet alles af. Intussen speelt deze bescheiden uitbreiding van de terminologie hier, bij de behandeling van deze gesloten woordsoort, nog nauwelijks een rol.

Het materiaal, waarop de beschrijving rust, is, zoals ook bij de beschrijving van andere delen der Javaanse morfologie het geval was, afkomstig uit twee bronnen, nl. uit interviews met informanten 5 en uit teksten, die hoewel grotendeels vóór de tweede wereldoorlog verschenen, toch wel als specimina van het Javaanse taalgebruik van het midden van deze eeuw te beschouwen zijn. Vanzelfsprekend kan dit materiaal hier slechts voor een klein gedeelte worden afgedrukt. Indien niet uitdrukkelijk het tegendeel wordt vermeld, mag aangenomen worden, dat de opgenomen gevallen van taalgebruik altijd een collectie van gelijksoortige gevallen representeren. Voor een brede empirische basis, zo essentieel voor linguïstisch onderzoek, is dus zo goed mogelijk zorg gedragen, al ben ik mij er wel van bewust, dat desondanks voor degene, die een andere taal dan zijn moedertaal onderzoekt en die dit bovendien doet ver van het betrokken taalgebied, de toegang tot de feiten moeilijk blijft. Ik herhaal mijn reeds vroeger uitgesproken wens dat er in de toekomst Javaanse linguisten mogen komen, die zich afzettend tegen de hier gedane pogingen tot nauwkeurige descriptie van hun moedertaal, tot een dieper inzicht en een scherpere formulering van de feiten geraken.

5 Dezelfde personen die mij ook vroeger hebben bijgestaan, nl. de heren Slamet Roosman, Soejono en mijn assistent J. Soegiarto. 


\section{ALGEMEEN OVERZICHT}

Er bestaan in het Standaard-Javaans een aantal deiktische woorden die een zeer nauwe samenhang vertonen. Ik noem hen in het hierna volgende pronomina, daarbij afwijkend van wat in de grammatica's van het Javaans gewoonte is. Als men overigens gebruik maakt van de traditionele termen (waartegen naar men weet geen bezwaar bestaat, zolang men hen slechts gebruikt als etiketten voor bepaalde groeperingen in een bepaalde taal), dan kan men onderscheiden $1^{\circ}$ pronomina personalia, $2^{\circ}$ pronomina demonstrativa, $3^{\circ}$ pronomina interrogativa et indefinita. Terwille van de overzichtelijkheid de kramaen zgn. madya-vormen en ook de verschillende colloquiale en verkorte vormen voorlopig buiten beschouwing latend - zij zullen ter sprake komen in de paragrafen die aan de verschillende groepen afzonderlijk zijn gewijd -, kunnen wij van de wijze waarop deze drie groepen zich onderling verhouden, door middel van het hieronder volgende schema een eerste indruk geven.

\begin{tabular}{|c|c|c|c|c|c|c|}
\hline PERSONALIA & \multicolumn{6}{|c|}{ DEMONSTRATIVA } \\
\hline & neutragl & & modal & $\begin{array}{l}\text { direc- } \\
\text { tioneel }\end{array}$ & $\begin{array}{c}\text { quanti- } \\
\text { tatief }\end{array}$ & \\
\hline aku & iki & kene & měñkene & mrene & sĕmene & sěprene \\
\hline kowe & iku & kono & měnikono & mrono & sěmono & - \\
\hline ḍeweqe & kae (ika) & kana & měñkana & mrana & sěmana & sěprana \\
\hline \multicolumn{5}{|c|}{ INTERROGATIVA ET INDEFINITA } & & \\
\hline sapa & apa & ĕndi & kěpriye & - & pira & kapan \\
\hline
\end{tabular}


Bepalend voor de vorm van dit schema zijn drie overwegingen geweest, nl. 1. de drievoudige onderscheiding die zich bij de pronomina personalia voordoet, vertoont overeenkomst met die welke bij de groep der demonstrativa optreedt, 2 . de onderscheidingen binnen de groep der demonstrativa herhalen zich vrijwel geheel bij de pronomina interrogativa et indefinita, 3. er zijn morfologische en syntactische redenen om sapa, wie, in één kader te plaatsen zowel met de pronomina personalia als met de pronomina interrogativa et indefinita. Deze drie overwegingen zullen nader gespecificeerd worden in de volgende paragrafen. 


\section{Pronomina personalia}

De woorden $a k u$, ik en kowe, jij nemen in het Javaans morfologisch en syntactisch een eigen positie in. Afgezien van nog nader hieronder te behandelen gevallen van transpositie naar de verba en naar de telwoorden zijn op basis van deze twee woorden slechts pronominale afleidingen te vormen met het suffix - $a$ (akua en kowea) en - waarschijnlijk alleen in een of meer Javaanse dialecten - met het suffix -ne (akune en kozvene). Ze kunnen tezamen met lan een woordgroep vormen, waarbij zij van plaats verwisselbaar zijn: naast $a k u$ lan kowe kan ook kowe lan $a k u$ voorkomen. Aku lan kowe lijkt echter frequenter te zijn. Zonder lan vormen zij een samenstelling, waarbij de volgorde van de samenstellende delen vast is: slechts $a k u$-kowe is mogelijk, niet kowe-aku.

Met Benveniste ${ }^{6}$ kunnen we de betekenis van aku omschrijven als het woord dat de spreker anduidt van de zin, waarin $a k u$ voorkomt. De Javaanse grammatica's plegen op te merken, dat aku niet alleen de spreker, ik, aanduidt, maar ook ik en de anderen, wij. Dit is niet geheel juist. $A k u$ duidt als regel slechts de spreker aan; wil $a k u$ betekenen: ik en de anderen, dan is dat zonder nadere pluraliteitsaanduiding alleen mogelijk, als reeds uit de situatie of de context vaststaat, dat $a k u$ niet anders dan dit betekenen kan. Wil men bepaald wijzen op: ik en de anderen, dan is gebruik van woorden als kabeh, pada, kĕtĕlu 7 beslist noodzakelijk. Zo bijv. aku kabeh paḍa klěbus, katisěn, ñẹtuțus (TB 55, 1, laatste regel), wij allen waren kletsnat, rillerig van de kou (en zaten) zielig in elkaar gedoken; aku kětělu mungah sěpur ana in sětatsiyun Pasarturi (OP 24, 12-13), wij met ons drieën stapten op het station P. op de trein. Voor kowe, het woord dat de persoon aanduidt tot wie de zin gericht is waarin kowe voorkomt, geldt het zelfde. Zo vindt men bijv. in het kinderblad Taman Botjah in de correspondentie-rubriek van Boe Mar na de zin Cah, kene

6 E. Benveniste, La nature des pronoms, For Roman Jakobson, 1956, p. 34-37

7 Ook combinaties zijn mogelijk; behalve aku kabeh pada klěbus is ook mogelijk aku kabeh klëbus, aku pada klěbus en ook aku pada klěbus kabeh. Echter niet: aku klěbus kabeh. De syntactische regels die de groepsvorming beheersen moeten we hier buiten beschouwing laten. 
pada lingihan mbi Bu Mar (TB 80, 2, 1), kinderen ga hier eens zitten samen met B. M., even verder: kowe wis kruinu orĕge, saiki nagara Walanda sida ditěmpuh Jĕrman... nañin kowe ora prĕlu kuwatir (TB 80, 2, 6-7 en 11-12), jullie hebben vast al de ontzettende tijding vernomen, dat Holland werkelijk door Duitsland is aangevallen... maar jullie behoeven niet bezorgd te zijn. Of in de situatie van een onderwijzer die voor de klas staat: nañin aku ěmoh mbĕboḍo marà kowe; malah kowe daqkudan dadia woń pintěr (BG II, 54, 11-12), maar ik wil jullie niet om de tuin leiden, integendeel ik wil, dat jullie knappe mensen worden.

Zoals ik reeds opmerkte is op basis van aku en kowe suffigering van - $a$ mogelijk, alleen echter in zinnen als akua, mĕsți něsu, als ik het geweest was, zou ik zeker boos geworden zijn; akua kae, měsți nĕsu, zelfs ik, zou zeker boos geworden zijn. Of suffigering van -ne mogelijk is, hebben we niet met zekerheid kunnen vaststellen; de enkele gevallen van gebruik waarover ik beschik, zijn afkomstig van mijn informant uit Banjumas en zijn door mijn twee andere informanten niet bevestigd, terwijl ik ook uit teksten geen gevallen van gebruik van deze vormen ken. Akune, kowene zouden betekenen wat mij, wat jou betreft, bijv. bu, apa aku maikat saiki waae, $(\mathrm{Sj})$, moeder, zal ik nu maar weggaan?, waarop de moeder vraagt: lah kowene kĕpriye, wat jou betreft, hoe zit het (wat wil je)?

Het is niet te verwonderen dat in een taal waarin verschil in sociale positie zo sterk tot uitdrukking komt, juist bij de pronomina personalia veelvuldig transposities van bepaalde substantiva en substantief-samenstellingen plaats vindt. Daar de spreker zich sociaal moet of gaarne wil achter stellen bij de toegesproken persoon is kula, het normale kramaequivalent van $a k u$ in allerlei omstandigheden hiertoe niet voldoende en ligt vervanging door verschillende substantiva die uw dienaar o.i.d. betekenen voor de hand. Zo is naar bekend is, in gebruilk abdidalĕm, verkort tot adalěm en dalěm, naast kareula. De positie van de Javaanse vorst bracht voorts mee dat hij naar zichzelf verwijzend behalve $a k u$ ook speciale termen als insun (verkort tot sun) gebruikte, terwijl de spreker zich tot de vorst richtend nog weer andere, meer nederige expressies ter aanduiding van zich zelf behoefde. Wat men bij het pronomen personale van de 1 ste persoon aantreft, vindt men mutatis mutandis bij de pronomina van de tweede persoon. De spreker zal vaak de neiging hebben of de verplichting voelen de toegesprokene hoger te stellen dan zich zelf en daarom de normale krama-equivalenten sampeyan en pañjĕněnian te vervangen door substantiva of substantief- 
verbindingen die - zo zou men misschien het beste samenvattend kunnen zeggen - de toegesprokene op een voetstuk plaatsen. Daar hij geacht wordt ook in feite hoger te staan dan de spreker die zich vanuit een nederige houding tot de hoger geplaatste richt, zijn substantieven als pars pro toto in gebruik die oorspronkelijk $U_{w}$ voeten of Uw voetzolen betekenen (bijv. pakĕnira uit tělapakĕnira), maar die in meer of mindere mate vervormd, synchronisch niet anders zijn dan beleefde equivalenten van pañjĕnĕnian. In zulke gevallen kan uiteraard niet meer van transpositie gesproken worden. Vele van deze termen worden of werden in ambtelijke verhoudingen nog wel gebruikt waarbij vaak op subtiele, kunstmatige wijze wordt gedifferentieerd tussen hen. Men treft hen voorts regelmatig nog in literair taalgebruik aan. Wij zullen hier geen poging doen om de diverse gevallen volledig op te sommen, omdat wij dan te zeer op lexicografisch terrein zouden komen. Wij verwijzen naar de grammatica's van Poensen en Walbeehm, die nogal wat van deze pronominale aequivalenten opgeven, en naar de woordenboeken.

Naast kozve staan als madya-termen dika en samain, deze laatste vaak verkort tot main, waartussen ik geen semantisch verschil heb kunnen vaststellen, als krama-termen zoals reeds opgemerkt, sampeyan en pañjěněnan, waar tussen echter wel een duidelijk verschil bestaat; sampeyan is heel wat minder beleefd dan pañjěněñan, de normale beleefde krama-term, ja kan als onbeleefd worden ervaren, wanneer de toegesprokene zich iemand van stand acht. Op vermakelijke wijze blijkt dit bijv. in OP 24, 24-31 waar Pétroek met zijn vrouw en Boe Mar keurig uitgedost en zich een echte prijaji voelend, in de trein met een vreemdeling een praatje wil maken, en beleefd vraagt: Pañjĕněñan bade tindaq pundi, maar kortaf tot antwoord krijgt: Hěh, Sĕmaraí, sampeyan... (OP 24, 26-27). In een brief aan Garèng meldt hij het incident en klaagt: Dadi aku katčlu pĕțane: běndara bei sakaliyan, karo putrane wadon tiniq-tiniq ${ }^{8}$, jĕbul takon uwon ana in sěpur, disěntaq, karo disampeyan (OP 24, 31-33), dus wij met ons drieën ciachten dat wij waren: mijnheer en mevrouw de raden bei met hun beeldige dochter, en daar worden we waarachtig als we een vraag stellen aan iemand in de trein, bars met sampeyan toegesproken!

Dat bepaalde substantiva en titels vaak voor voornaamwoorden in de plaats treden hangt behalve met de behoefte aan sociale differentiatie, ook samen met het feit, dat het gebruik van voornaamwoorden in het

8 Met anomale i-variant: ținíq-ținiq. 
algemeen in bepaalde situaties door hun directheid als onbeleefd of zelfs grof wordt beschouwd. Kowe is het normale ngoko-voornaamwoord dat gebruikt wordt, wanneer spreker en toegesprokene elkaar kennen of wanneer iemand zich richt tot een hem al of niet bekend persoon van lagere sociale status. Kent men elkaar intiem maar is er toch een zeker status-verschil (bijv. jongere tegenover oudere broer of zuster) dan zal men niet kowe, maar slirane of sliramu gebruiken. Awaqe dat eveneens als voornaamwoord van de 2 de persoon voorkomt, is gelijk te stellen met kowe. Indien men wanneer slirane of sliramu op zijn plaats is, toch met kow'e aanspreekt, zal dit als niet passend worden ervaren. Zo zal in een rechtzaak de rechter, ngoko sprekend tegen de beklaagde, slechts van kowe gebruik maken als hij zich boos maakt en bijv. tegen beklaagde uitvalt. Men zal tegen zijn jongere broeder kowe gebruiken zonder dat zulks voor deze ook maar enigszins kwetsend is. Men zal echter de neiging hebben dit achterwege te laten indien onbekenden of weinig bekende derden aanwezig zijn. In situaties, waarin madya op zijn plaats is, kunnen samain en dika door verschillende termen vervangen worden. Zo zegt de nieuwe immigrant in het kolonisatiegebied tegen de jongere chauffeur van de autobus, die tot zijn blijde verrassing een landgenoot blijkt te zijn (AMK 39, 7) : lo si mase niku dadi tiyain Jawi, he, mas, bent $U$ een Javaan? En in de roman van Asmawinangoen, Saking papa doemoegi moelja, zegt iemand die kennis wil maken : manuhakěn, sĕdereqe pundi? (BD 78, 9), laten we met elkaar kennismaken, waar komt u vandaan?

De mogelijkheden van transpositie van aku en kowe naar andere woordsoorten zijn niet gelijk. De enige gevallen van verbale transpositie bij kowe zijn dikowe en nowe, kowe zeggen, iemand met kowe bejegenen, waarnaast ook taqkowe en koqkowe mogelijk zijn, maar waarvan wij geen schriftelijke gevallen van gebruik kennen; wel echter van de parallelle vormen disampeyan en ñampeyan (OP 24, 31 en 26, 12 en 30$)$.

Bij $a k u$ zijn er meer mogelijkheden. Daarbij valt op dat bij transpositie naar de verba de corresponderende krama-termen akĕn-vormen zijn en dus niet op basis van kula worden gevormd. Zo staat bijv. naast diaku, dipunakĕn, naast ṅakoni, nakěni, naast akon-akon, akĕn-akěnan.

Ook op basis van aku kan als bij kowe, een verbale vorm zonder suffix worden gevormd: $\dot{n} a k u$, bekennen, beweren, zich uitgeven voor, vooral voorkomend in groepen als: $\dot{n} a k u$ anaq, als kind erkennen en $\dot{n a k u}$ gagah, zich uitgeven voor flink. Het is echter de vraag of aan de formele parallellie van iaku en nowe ook een semantische parallellie 
beantwoordt. Er is daarom ook twijfel, omdat naast $\dot{n} a k u$ / diaku voorkomt nakoni/diakoni, iets erkennen, terwijl corresponderende, op kowe gebouwde -i-vormen ontbreken. De semantische verhouding tussen dit $\dot{n} a k o n i$ en $\dot{n} a k u$ is wel gelijk aan die, welke wij normaal in het centrale verbale paradigma aantreffen tussen de vormen met suffix $i$ en die zonder suffix. ${ }^{9}$ Het bestaan van een vorm $\dot{n}$ akoqake, die vermeld wordt in het woordenboek van Gericke-Roorda hebben we niet kunnen vaststellen. Dit wil niet zeggen dat wij het uitgesloten achten, dat zulk een werkwoord voorkomt; wellicht dat als de behoefte er aan zich doet gevoelen het toch gevormd wordt.10 Naast iaku komen tenslotte regelmatig voor pañaku of pěriaku, bekentenis 11 , ook met suffigering met -ne: p̌̌niakune, dat formeler is dan het alledaagse nakune; voorts $\dot{n} a k u-a k u$, dat in verhouding tot $\dot{n} a k u$ een betekeniselement van onbepaaldheid en vaagheid bezit, bijv. saupami kula $\dot{n} g a-$ dahana manah rumaos sagĕd amadaini, punika nama ìaken-akěn, inger (SK 75, 12-13), gesteld dat ik het idee had, dat ik in staat was voorlichting te geven, dan zou dat zeker heten : zich (zonder grond) op

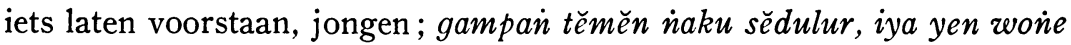
gělěm, yen ora, hla raq malah klejin pin pat. Bab iaku-aku kuwi

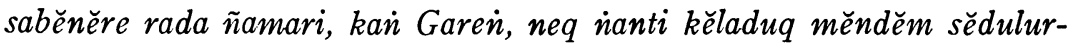
sĕduluran, bisa mbubrahake aìka ( $\mathrm{K}$ 1190, 1, 11-16), beweren iemands broeder te zijn is erg makkelijk, d.w.z. als de persoon in kwestie dit inderdaad (van zijn kant) wil, maar als dat niet het geval is, dan sta je zelfs falikant (= vier maal) voor gek. Zo iets zo maar beweren dat is eigenlijk nogal gevaarlijk, Garèng, als je je teveel bedrinkt aan de gedachte van verbroedering, dan kan de boel in het honderd lopen, en met waarschijnlijk compensatorische verdubbeling 12 akon-akon, wat als het zijne erkend is, toegeëigend, vooral in de groep bocah akon-akon, een erkend kind (nooit bocah akon). Het bij GerickeRoorda opgegeven akon, bij wijze van voorgeven, kwansuis, was aan onze informanten onbekend, werd ook niet aangetroffen in modernJavaanse teksten en is ook bij Pigeaud niet te vinden.

9 Zie over het verschil tussen de beide verbale categorieën: The structure of the Javanese Verb, For Roman Jakobson 1956, p. 570-571.

10 Een van onze informanten $(\mathrm{Sg})$ meende dat een zin als ěrigone nakoqake amaq bocah mau srana lapuir maran lurah kampun, hij heeft de jongen als zijn eigen kind laten erkennen door aangifte bij het kamponghoofd, heel goed zou kunnen voorkomen. Nadere gegevens zijn echter gewenst.

$11 \mathrm{Zie}$ over het verschil tussen beide vormen BKI 111, 3 (1955), p. 294-295. Onder rooms-katholieke Javanen is de term pěñakunin dosa voor biecht in gebruik gekomen.

12 Zie voor deze term BKI 109 (1953), p. 58. 
Transpositie naar de telwoorden is bij aku mogelijk door prefigering van $s a$-, met emfase saq-. Saqaku of saaku betekent dan zo iemand als $\mathrm{ik}$, zo groot als ik. Enige zinnen uit teksten: wah bansa ninrat kuwi angĕpe kaya putrane malaekat jibril, neq karo banisane saaku kiyi angone katon: ewa, cěmĕri-črri (OP 33, 10-12), ach die ningrat's beschouwen zich zelf als kinderen van de engel Gabriël, tegenover landgenoten van mijn slag blijken ze vol afkeer en tegenzin te staan; napa saqkula niki keniin upamine ñelenii tě̀ posěparbà் niku? (SDS $30,1-2)$, mogen mensen zoals ik bijv. sparen bij die postspaarbank? Ook op basis van het compositum aku-kowe is deze formatie mogelijk: kango won-woin saaku-kozve, wis ora ana lucu lan ramene, wis bosĕn, Truq (BD 159, 20-21), voor mensen als jij en ik, is er niets leuks en prettigs (meer) aan, we zijn het al beu, Troek.

Het fundamentele onderscheid tussen de pronomina personalia van de eerste en de tweede persoon enerzijds en die van de derde persoon anderzijds, waarop Benveniste zo terecht de aandacht heeft gevestigd ${ }^{13}$, is ook zichtbaar bij de Javaanse persoonlijke voornaamwoorden. Tussen $a k u$ en kowe bestaat duidelijk overeenkomst, deweqe staat geheel van deze voornaamwoorden gescheiden. Parallel hiermede loopt hetgeen we zagen bij de pronominale prefixen en suffixen die resp. bij verba en substantiva optreden. De verba met taq-, daq- en ko-, koq- staan tegenover de verba met prefix $d i$, de substantiva met $-k u$ en $-m u$ staan tegenover de substantiva met $-e$ of $-n e$, als de verba, c.q. de substantiva die wel een referentie bevatten naar de deelnemers aan de spraakbehandeling, en zij die zulk een positieve indicatie niet bevatten. In een schema verenigd (met weglating van de madya- en krama-aequivalenten)

\begin{tabular}{|c|c|c|}
\hline $\begin{array}{c}\text { pronomina } \\
\text { personalia }\end{array}$ & $\begin{array}{c}\text { pron. prefixen } \\
\text { bij de verba }\end{array}$ & $\begin{array}{c}\text { pron. suffixen } \\
\text { bij de substantiva }\end{array}$ \\
\hline $\begin{array}{l}\text { aku } \\
\text { kowe }\end{array}$ & $\begin{array}{l}\text { taq-, daq- } \\
\text { ko-, koq- }\end{array}$ & $\begin{array}{l}\text {-ku/-aku } \\
-\mathrm{mu} / \mathrm{amu}\end{array}$ \\
\hline deweqe & di- & $-\mathrm{ne}$ \\
\hline
\end{tabular}

Het gebruik van deweqe of deweqne ${ }^{14}$ (waarnaast in de spreektaal

13 Benveniste o.c.

14 cf. bapaqe / bapaqne; niettemin is dezveqe / derweqne niet meer als een polymorfematisch woord met suffix $\rightarrow$ lle te beschouwen. 
vaak deqne en met schijnbaar dubbele suffigering 15 deqnene), krama: piyambaqipun of kiyambaqipun, madya piyambaqe of kiyambaqe, hij, $\mathrm{zij}$, die man (vrouw), is zeer onvolledig beschreven.

Juist is het dat deze woorden in het Javaans weinig worden gebruikt, al is daar zoals wij nog zullen zien, onder vreemde invloed een kentering in gekomen. Dit heeft twee redenen. De eerste is van syntactische aard. Het Javaans kent niet het gebruik van substituts abréviatifs, om een term van Benveniste te gebruiken.16 Waar de Fransman zegt: Pierre est malade, il a la fièvre, de Nederlander Piet is ziek, hij heeft koorts, zal de Javaan in een overeenkomstig geval 17 zeggen: Amat měñan pasar, ingawa buntělan, Amat is naar de markt, hij heeft een pakje bij zich, dus zonder dat een anaforisch element voor $\dot{n}$ gawa, het tweede werkwoord, optreedt. De tweede reden hangt samen met de grote rol die sociaal verschil in het Javaans speelt. In alle gevallen waarin een spreker moet refereren naar een persoon die een hogere sociale status heeft dan hij zelf, is gebruik van derveqe of piyambaqipun nl. uitgesloten.

Maar het taalgebruik omvat uiteraard andere gevallen waarin de sociale verhouding tussen spreker en de persoon waarnaar hij refereert. gebruik van deweqe c.q. piyambaqipun niet in de weg staat. De volgende passage laat duidelijk zien hoe piyambaqipun achterwege blijft als de sociale verhoudingen zich daartegen verzetten, maar optreedt daar waar deze zulks toelaten: sarĕn pun kakaì tuzein adalěm sampun mĕdal, iñriku pun kakan் bade nuluñi titiyan் sagĕdipun éngal mĕdal, pun

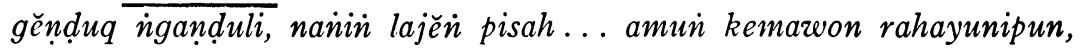
gusti, lajĕn wontěn inkain wĕlas, wontěn tiyan neneman satungal ananți piyambaqipun, lajĕn kabĕkta mĕdal sakin in alun-alun, zo vertelt de vrouw van adipati Pramayoga aan de moeder van Raden Mas Rijanta (SR 60, 9-15), toen mijn man en ik buiten gekomen waren (uit het brandende gebouw), toen ging mijn man de mensen helpen om snel naar buiten te komen, ons kind klemde zich aan hem vast, maar raakte van hem gescheiden... maar gelukkig, mevrouw, was er iemand die zich om haar bekommerde, een jongeman nam haar bij de hand, en zo werd ze vervolgens buiten de aloen-aloen gebracht. Naar haar man refereert de spreekster dus met pun kakan, naar haar dochter met piyambaqipun.

15 Analoog aan jarene, turene.

16 Benveniste, La nature, p. 37.

17 We kunnen hier niet de Javaanse vertaling van de Franse zin van Benveniste gebruiken, deze zou immers luiden eenvoudig: Piet lara panas. 
Gaan we nu de gevallen na waarin deweqe en piyambaqipun voorkomen, dan blijkt dat zij allereerst optreden om op enigszins denigrerende wijze naar een derde te verwijzen, bijv. yen kowe arĕp ñanaq deqe, ya sakarĕpmu; neq aku ora sotir (KA 3, 20-21), als jij vriendschap wil sluiten met diè jongen, dan moet je dat zelf weten, ik heb er geen zin in; weh, namari toq bae, kan Gareñ kae. Won deweqe kuwi soq ora irěti duga prayoga ( $\mathrm{BD} 152,3-2$ v.o.), hè, wat is die Garèng daar toch voortdurend vervaarlijk in de weer, die kerel weet soms niet hoe hij zich moet gedragen.

In de tweede plaats vindt men derveqe c.s. in beschrijvend proza in zinnen met een samengestelde woordinhoud, waar zonder gebruik van een anaforische term een zekere onduidelijkheid zou ontstaan of waar gebruik van deweqe vóór het tweede werkwoord van de zin met nadruk verwijst naar het substantief of het naam of titel aanduidend woord dat met het eerste werkwoord in de zin is verbonden, bijv. rara Sripeni lajĕn $\dot{n}$ gadahi pangraita, geq kadospundi bab sěrate kěkasihipun, koq piyambaqipun botěn dipunsukani suměrěp in tiyan sĕpuhipun (OA 40, $10-12$ ), Sripèni vroeg zich af, hoe het toch zat met de brief van haar geliefde, dat zij (zelf) nota bene niet door haar ouders ingelicht was. Het is mogelijk dat in deze zin piyambaqipun wordt weggelaten. Hierdoor zou wel een zekere mogelijkheid tot misverstand zijn geschapen, hoewel juist begrip voor de lezer, c.q. de hoorder nog geenszins uitgesloten zou zijn. Toevoeging van piyambaqipun sluit evenwel niet alleen iedere twijfel uit (piyambaqipun kan niet anders dan naar rara Sripeni verwijzen), maar legt daar ook een zekere nadruk op: zìj (of all people) was nog niet ingelicht! Hierbij sluiten zich de gevallen aan waarin naar een bepaald persoon wordt gerefereerd in een zeker contrast met anderen, bijv. akeh bocah sin wis kĕmba kĕkañcan karo derveqe, bañjur sěnĕn mĕñai Sucitra lan Sukarman (KA 19, 6-7), veel jongens wier animo om met hèm om te gaan verflauwd was, raakten toen op Sutjitra en Sukarman gesteld.

In het algemeen bemerkt men dat het groepen met karo, kaliyan of marai zijn waarin deweqe, c.q. piyambaqipun het veelvuldigst in verbinding voorkomt. Soms aarzelt men dan of men deze gevallen moet rekenen tot de hierboven besprokene of dat men hen dient te beschouwen als het gevolg van Nederlandse invloed. Zo zijn in de zin ...mulane aku sĕnĕn sobatan karo deweqe (PPB 31, 10-11), daarom vind ik het prettig bevriend te zijn met hem, de woorden karo derweqe geenszins weglaatbaar in het verband, waarin deze zin voorkomt. Echter in de zin: tiyañ-sĕpuhipun lare estri wau botĕn bade ìemah-emahakĕn 
anaqıpun manawi botĕn ansal anaqin sudagar inkan kĕcěkapanipun sami kaliyan piyambaqipun (OA 6, 11-13), de ouders van dat meisje zouden hun kind niet willen uithuwelijken, als ze niet een kind van een handelaar kreeg wiens rijkdom gelijk was aan die van henzelf, zou waarschijnlijk in wat ouderwetser Javaans de laatste twee woorden kaliyan piyambaqipun weggelaten zijn, hoewel ik hier toch ook nog aarzel om hun aanwezigheid met zekerheid aan Nederlandse invloed toe te schrijven. Deze invloed is overigens in andere gevallen onmiskenbaar.

In de periode van \pm 1920 tot aan de bezetting van Java door Japan, waarin het onderwijs in het Nederlands aan Javaans sprekenden een belangrijke uitbreiding onderging, lijkt $\mathrm{nl}$. het gebruik van deweqe en piyambaqipun duidelijk toegenomen. De resultaten van een beperkt vergelijkend frequentie-onderzoek van schriftelijk gebruik wijst tenminste in die richting. In een drietal Volkslectuurboekjes verschenen omstreeks 1923, kwamen op een totaal van 193 pagina's ( \pm 65.000 woorden) dezeeqe en piyambaqipun samen slechts 13 keer voor, terwijl in twee naoorlogse uitgaven (tezamen 226 pagina's, \pm 51.000 woorden) dit 78 maal gebeurde. ${ }^{18}$ Van deze 78 gevallen kon bovendien in verreweg de meeste deweqe of piyambaqipun weggelaten worden zonder dat dit enig betekenisonderscheid leek te veroorzaken. Enkele voorbeelden: saběn dalu rara Sripeni botěn kĕndat ñĕñuzun datěn Pañeran saha datĕn bapa-biyunipun ïnkà sampun botěn wontěn, supados piyambaqipun tumuntěna uwal sakin cĕ̀nkĕrĕmanin bapa-biyunipun aikat (OA 13, 11-14), iedere avond smeekte Sripèni steeds aan God en haar overleden ouders, dat zij terstond bevrijd zou raken uit de klauwen van haar pleegouders. Uit een in 1940 verschenen werkje: neq wainsulane sĕnĕn, derveqe melu sĕnĕn, neq susah, melu susah (PPB 33, 5-6), als hij antwoordde: tevreden, dan was hij ook tevreden, als hij zei : susah, dan was hij ook verdrietig.

Dat dit toenemend gebruik door het Nederlands geïnduceerd is, blijkt uit het feit dat in vertalingsproza dezveqe en piyambaqipun zeer frequent zijn, eveneens in gevallen waarin vanuit ouder taalgebruik gezien voor het gebruik van deze woorden geen aanleiding is. Zo is bijv. het blad voor economische voorlichting Ekonomi Rajat, dat voor de oorlog door

18 Gekozen werden de boekjes Kamsa, Soepraba lan Soeminten, 1923 (deweqe -, piyambaqipun 6), M. S. Sastradiardja, Soekatja, 1923 (deweqe 1, piyambaqipun 2), R. B. Soelardi, Serat Rijanta, 1920 (derveqe 2, piyambaqipun 2), tegenover Th. Suroto, O, anakku, 1952 (derveqe 10, piyambaqipun 52), R. Hardjawiraga, Sri Kuning, 1953 (dereqe 4, piyambaqipun 12). 
Balé Pustaka werd uitgegeven, een rijke bron voor gevallen van deweqe, evenals bijv. het boekje Piet Pon Blès, waaruit we hierboven citeerden, een werkje dat naar ik mij meen te herinneren, op verzoek van de vereniging voor dierenbescherming als Javaanse bewerking van een Nederlands gegeven kort voor de 2de wereldoorlog uitkwam.

Deweqe kan verbonden worden met pronomina van de $i k i$-reeks, bijv. saiba upama deweqe iku sawijine woǹ kañ wis oleh pénajaran ... (GW I 9,8), hoe zou het wel geweest zijn, als hij iemand was die onderwijs had genoten; pañcen piyambaqipun punika botěn rěměn datěn bĕbakulan, rĕmĕnipun dados bojon priyantun (OA 30, 2 v.o.), eigenlijk houdt zij niet van koopvrouw worden, wat ze wil dat is de vrouw van een prijaji worden. De toevoeging van $i k u$ of $k u$ wi c.q. punika bewerkt een lichte nadruk. 


\section{PRONOMINA DEMONSTRATIVA}

\section{Algemene karakteristiek}

Terwijl in de Javaanse morfologie in het algemeen de vormprocédé's van affigering en verdubbeling overheersen, treedt bij de pronomina demonstrativa het procédé van interne wijziging van de klankvorm op. Er bestaat daarbij tussen de verschillende series een grote mate van eenvormigheid: steeds heeft de wijziging uitsluitend betrekking op het vocalisme. Vrijwel altijd betreft zij de paenultima- en ultima-vocaal; als regel heeft de eerste horizontale rij een é-variant van het E-foneem, de tweede de ó-variant van het $\mathrm{O}$-foneem, de derde de á-variant van het A-foneem. ${ }^{19}$ Slechts de $i k i$-serie maakt hierop een uitzondering, al wordt ook daar de vorm van de eerste rij gekenmerkt door palatale vocalen, de tweede door velare vocalen.

Semantisch onderscheiden zich de pronomina van de drie horizontale rijen eveneens duidelijk van elkaar. In het algemeen wijzen de pronomina van de eerste rij in directe relatie tot de spreker van de zin waarin zij voorkomen, die van de tweede rij met betrekking tot de hoorder of althans met betrekking tot wat in de spreeksituatie present is of present wordt geacht, terwijl die van de derde rij ieder naar hun modaliteit (neutraal, locaal, modaal, directioneel, quantitatief of temporeel) wijzen op hetgeen zich afspeelt buiten de ,participants of the speechevent", waarin deze demonstrativa voorkomen. De samenhang met de pronomina personalia is, naar blijken zal, evident.20 Met de pronomina interrogativa et indefinita is er eveneens een duidelijke relatie: alle modaliteiten met uitzondering van de directionele, komen ook daar voor; bij de groep sěmene, sěmono, sěmana, pira is reeds bij de beschrijving der telwoorden 21 de onderlinge samenhang van de leden van deze groep in het licht gesteld.

19 Zie onze beschrijving van het Javaanse vocalisme, De structuur van het Javaanse morpheem, Verh. Kon. Bat. Gen. 78 (1949), p. $29-41$.

20 Het inzicht van Snouck Hurgronje in het karakter der pronomina personalia was ongetwijfeld heel wat juister dan dat van Kiliaan, cf. C. Snouck Hurgronje, Atjehsche Taalstudiën, Tijdschr. Bat. Gen. 42 (1900), p. 151-155; H. N. Kiliaan, Javaansche Spraakkunst 1919, p. 217-221.

21 BKI 109 (1953), p. 342-37.5. 
De demonstrativa vertonen verder ten aanzien van de morfologische procédé's die zich bij hen voordoen, en ook ten aanzien van de valentie kenmerkende overeenkomsten. $\mathrm{Zij}$ zullen bij de hierna volgende behandeling per serie duidelijk blijken.

Eveneens kenmerkend voor de groep zijn de beperkte mogelijkheden van combinatie onderling. Slechts pronomina van dezelfde serie kunnen gecombineerd worden. Binnen iedere serie kan uitsluitend een pronomen van de eerste rij met een van de tweede en derde gecombineerd worden: kene kan dus bijv. met kono en kana een samenstelling vormen, mrene uitsluitend met mrono en mrana. Maar kono kan niet met kana, mrono niet met mrana gecombineerd worden.

Bovendien zijn er bepaalde regels van groepsvorming. Is $i k i$ met een substantief als meja, tafel, verbonden dan kan meja nog slechts met een ander pronomen (of adjectief) verbonden worden, wanneer dit staat tussen meja en $i k i$ in (meja kene $i k i$ ). Komt een dergelijk pronomen of adjectief echter na $i k i$ (meja iki kene, meja iki bundĕr), dan vormt het niet met meja maar met de groep meja iki een - uiteraard samengestelde - groep.

De corresponderende ceremoniële termen vertonen hetzelfde beeld: ook daar zijn de vormverschillen verschillen in vocalen, al betreffen deze in sommige gevallen niet èn de paenultima èn de ultima-vocaal, maar slechts één van beide. In enkele series staat in de standaard-taal tegenover de drie ngoko-termen slechts één krama-term; in dialectisch krama of/en in madya is echter het parallellisme met de ngokopronomina ook in die gevallen volledig.

Er zijn echter ook enkele verschijnselen, waardoor ieder van de series van drie zich van de overige onderscheiden: niet overal zijn de transpositiemogelijkheden precies gelijk, er zijn verschillende afkortingsmogelijkheden, enz. Een seriegewijze behandeling kan daarom niet achterwege blijven.

\section{De iki-serie}

In deze paragraaf zullen de volgende, hieronder in een schema verenigde pronomina ter sprake komen.

\begin{tabular}{|c|c|c|c|c|c|c|c|}
\hline & & & I & & erkort. & II & III \\
\hline A & iki & kiyi & - & kiye & $\mathrm{ki}$ & (puniki) & niki \\
\hline B & iku & kuwi & - & kuwe & ki & (puniku) & niku \\
\hline C & (ika) & & kae & & ke & mĕnika & nika \\
\hline
\end{tabular}


De verdeling in de groepen I, II en III is een verdeling in ngoko-, krama- en zgn. madya-vormen. Mënika, vrijwel altijd geschreven als punika 22 treedt, hoewel qua vorm behorend tot de derde horizontale rij $\mathrm{C}$, als positief ceremoniële term bij alle drie rijen op. Men treft dus bij gebruik van krama měnika aan daar waar men in nietceremoniële taal $i k i$, iku dan wel kae zou ontmoeten. Er bestaat echter één uitzondering op deze correspondentie-regel: in bepaalde hieronder nog nader te noemen gebruiksgevallen van kae correspondeert niet měnika maar inatĕn, c.q. měkatěn met dit pronomen. Dat het krama hier slechts één demonstrativum heeft tegenover het ngoko drie, is niet verrassend. De aard van het krama verzet zich tegen een te grote explicietheid, verkiest naast omschrijving neutrale en gedepersonaliseerde aanduiding. In een situatie waarin men krama gebruikt, passen geen woorden als $i k i$ en $i k u$ die juist direct verwijzen naar spreker en hoorder.

Buiten het standaard-krama, in locaal-krama dus, schijnen ook de vormen puniki en puniku voor te komen ${ }^{23}$, zodat daar een volledige één tegen één correspondentie bestaat met de normale, niet verkorte ngoko-vormen. In gebonden taalgebruik, in tĕmbang lijkt op het eerste gezicht dezelfde toestand te bestaan, omdat men daar ook de vormen puniki en puniku aantreft. Bij nader toezien blijkt het voorkomen van deze vormen in dit taalgebruik echter geheel beheerst te worden door de eisen der Javaanse metriek: puniki en puniku worden gebruikt, waar het metrum vraagt om slot $-i$ of $-u$ en punika metrisch onmogelijk is. Van enige semantische parallellie met $i k i$ resp. $i k u$ is dan geen sprake, d.w.z. men kan in tĕmbang bijv. zeer goed puniki aantreffen waar in corresponderend ngoko-gebruik $i k u$ of $k a e$ op zijn plaats zou zijn geweest.

Groep III omvat de zgn. madya-pronomina. Naar de vorm zijn het verkortingen van de ceremoniële term(en). Niki, niku en nika worden vrijwel uitsluitend in mondeling gebruik gehanteerd ,,in het dagelijks contact met kooplui en andere min of meer bekenden, waartegen men

22 Ten onrechte stelt men in de beschrijvingen de geschreven vorm voorop. Punika zal hoogstens worden gehoord bij het voorlezen van geschreven taal. Geschreven zal men mĕnika alleen vinden in teksten die beogen het gesprokene zo natuurgetrouw mogelijk weer te geven.

$23 \mathrm{Z}$ ij worden voor zover mij bekend ook inderdaad als puniki en puniku uitgesproken, en niet dus als měnika en měniku. 
moeilijk krama kan spreken, maar die toch op een zekere beleefdheid aanspraak kunnen maken". 24

Vergelijkt men binnen groep I de vorm $i k i$ enz. met kiyi en kiye enz. dan blijkt, dat beide reeksen een klankstuk gemeen hebben (resp. $k i$, $k u$ en $k a$ ) maar van elkaar verschillen doordat bij de $i k i$-serie $i$ vóór dit klankstuk, bij de kiyi, kiye-serie $i$, resp. $e$ na dit klankstuk komt. Volgens de normale ook elders geldende regels 25 treedt dan bij kiyi, kiye een verbindings $y$, bij kuwi en kuwe een verbindings $w$ op, terwijl eveneens geheel normaal bij kae geen enkel consonantisch element tussen beide vocalen verschijnt.

Dat in het schema $i k a$ tussen haakjes is geplaatst, is geschied op grond van grotendeels dezelfde overwegingen als bij puniki en puniku. Ika komt nl. uitsluitend voor in těmbang waar om metrische redenen een A-foneem vereist is. Het kan dan optreden waar in niet-gebonden taal $i k i$, $i k u$ of kae zou hebben gestaan. Het is begrijpelijk dat in těmbang waar veelvuldig een A-foneem als slotvocaal wordt geëist, $i k a$ zich als enig ngoko-demonstrativum dat op - $a$ eindigt, weet te handhaven. Gevallen van bovengenoemd gebruik van $i k a$ vindt men bijv. in de Serat Joesoep, ed. Bale Pustaka no. 1444 (1941).

Het onderscheid tussen de vormen $i k i$ en kiyi, kiye en tussen $i k u$ en kuwi, kuwe correspondeert dus niet met het onderscheid dat tussen $i k a$ en $k a e$ bestaat. $I k i$ en $i k u$ zijn gelijkelijk op hun plaats zowel in mondeling als in schriftelijk gebruik. Kiyi en kuwi daarentegen zijn demonstrativa die vooral gebruikt worden in informele gesprekken van alledaagse aard. Kiye en kuwe hebben hetzelfde karakter als kiyi en kuwi, maar behoren niet voor alle taalgebruikers geheel tot de standaard-taal. Volgens één informant hoort men kiye en kuwe vaak in de mond van vrouwen. Onderzoek van teksten, waarin getracht wordt gesprekken zo natuurgetrouw mogelijk weer te geven, bevestigt deze laatste opvatting tot nu toe niet.

$\mathrm{Bij}$ hoger spreektempo komen in gemeenzame gesprekken de vormen $k i$ en $k e$ veelvuldig voor. Dat $k i$ en $k e$ verkortingen zijn van resp. $i k i$ en kae mag bekend worden geacht. Beide zijn gevormd volgens twee in het Javaans gangbare methoden van verkorting, die vroeger reeds besproken zijn. ${ }^{26}$ Enige gevallen van gebruik: $a k u$ ki arane

24 Aldus H. Th. Pigeaud, Javaans-Nederlands handwoordenboek, Groningen-

Batavia 1938, Voorrede p. iv, par. 16.

25 Cf. De structuur enz., p. 212-214.

26 De structuur enz., p. 59. 
diwalĕs (BD 132, 15 v.o.), men wreekt zich om zo te zeggen op mij hier; deq nu ke aku manan mangis ke ya lĕgi (LBK 19, 8), toen, bij die gelegenheid at ik die manggistan, zoet was die.

Naast het $k i$ dat een afkorting van $i k i$ is, komt in de spreektaal regelmatig $k i$ voor als verkorting van kuwi, een verkorting die dus volgens hetzelfde procédé gevormd is als $k e$ van kae. Enige gevallen van gebruik zijn: paq, lawaì dilénani ki men apa ta? (TB 72, 1, 24) vader, waarom worden deuren geolied?; těka gělis těmĕn ta taune kuwi. Aku ñjur krasa turea, Kap, dinane ki mlayu bae (TB 72, 2, 4-5), wat gaat het jaar toch snel. Ik ga me oud voelen, Kap, de dagen vliegen maar voorbij.

$\mathrm{Na}$ deze details komt thans het centrale vraagstuk aan de orde: de vraag naar de betekenisverhouding tussen de pronomina van de drie horizontale rijen A, B en C. Om deze te kunnen bepalen is het noodzakelijk de verschillende onderscheidingen na te gaan, die zich binnen de betekenis van ieder van deze pronomina voordoen.

Om te beginnen komen binnen de betekenis van kae de volgende onderscheidingen voor:

I. kae ter aanwijzing van hetgeen zich ruimtelijk buiten het hier en het nu van de spreeksituatie bevindt. Dit is het meest bekende gebruik van kae en ik kan daarom met het geven van enkele gebruiks-

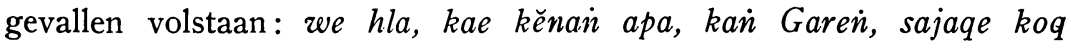
mëñcaq-mĕñcaq nĕsu ñan sopir (BD 140, 10-11), hé wat is daar ginds met (broer) Garèng aan de hand, dat hij daar, boos op de chauffeur, naar het wel lijkt pěntjak staat te spelen (zegt Pétroek tegen zijn vrouw en zijn schoonzuster als Garèng op een afstand van hen, het met een taxi-chauffeur aan de stok krijgt); wis cilaka sin kula nuwan-kula nuwun kae, kaya-kaya kaume (BD 139, 6-5 v.o.), wat een pech, die daar ginds aan het kula-nuwun roepen is, dat zal wel de kaum zijn (zegt Pétroek teleurgesteld omdat de komst van de kaum aan hun kaartpartijtje op Lebaran zeker een einde zal maken).

II. kae wijst aan hetgeen temporeel buiten het moment van het spreken ligt, in de volgende gevallen: kae mau sapa ta, lehe urmat koq taqlim bainèt? (Sg), wie was dat toch daar net, die zo eerbiedig groette?; mĕńko siq. Truq, saduruñe ambañjurake rěmbugane lagi anu kae, aku takon maran் jĕnĕñ sira... (BD 176, 8-9) wacht even, (Pé)troek, voordat we dat gesprek van die keer toen voortzetten, vraag ik eerst aan Uwe Hoogheid... Duidelijk is ook dit verwijzen van kae naar wat temporeel buiten de spreeksituatie ligt, wanneer mau 
$k a e$, daarnet, gecontrasteerd wordt met $i k i$ mau, net nog. In de zin: lo, gumun aku, mau kae jarene ora luwe, koq saiki nadĕp pañanan saqpirin ( $\mathrm{Sg}$ ), hé, daar sta ik van te kijken, daarnet zei je geen honger te hebben, maar nu ga je voor een bord vol versnaperingen zitten, kan mau kae vervangen worden door iki mau, dat betekent, net nog, zo kort geleden dat het nog om zo te zeggen in het heden ligt. Mau kae daarentegen betekent eenvoudig: die keer toen, een zekere tijd geleden, geheel buiten het nu van de spreeksituatie. In bovenstaande zin maakt daarom $i k i$ mau de tegenstelling tussen de verklaring van geen honger te hebben en het onmiddellijk weer aan 't eten gaan, veel scherper dan wanneer mau kae wordt gebruikt.

III. Direct zich aansluitend bij het temporeel aanwijzend gebruik is het gebruik van kae om te verwijzen naar een omstandigheid die aan spreker en toegesprokene bekend is. Dit zal vaak een in het verleden liggend feit zijn. Zo bijv. aku biyen tambane sin irĕ $\dot{n}$-irěr

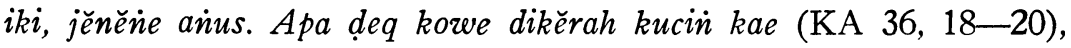
ik heb vroeger dit zwarte middeltje gehad, nl. roet. Was dat toen je (indertijd, die keer weet je wel) door een kat was gebeten? (vraagt de andere jongen). In deze zin hoort kae niet speciaal bij kucin, maar via $d e q$ bij de gehele groep deq kowe dikěrah kucin. Kae in deze zin wordt altijd op deze wijze gebruikt: aan het eind van een woordgroep. en dus niet direct verbonden met het woord dat onmiddellijk aan kae voorafgaat, tenzij natuurlijk woordgroep en woord samenvallen.

IV. Er zijn nu echter ook gevallen, waarin kae geheel op dezelfde wijze aan het eind van en behorend bij een woordgroep optreedt, maar waarin ieder element van verwijzing naar een in het verleden liggend feit ontbreekt. Kae betekent in die gevallen dan zo ongeveer : zoals je weet, op die bekende wijze. Gevallen van dit gebruik: ramene ěngone takontakonan wis kaya měñan sadulure dewe kae (AMK 40, 9-10), de levendigheid, waarmee zij bij elkaar naar allerlei informeerden, was precies zoals men dat pleegt te doen - zoals je weet - bij z'n eigen

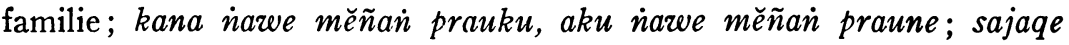
kaya wis těpun běciq kae (AMK 31, 19-21), ginds wuifde men naar ons schip, wij wuifden naar hun schip, zoals men pleegt te doen, weet je wel, als men elkaar goed kent. Hoezeer bij dit gebruik van kae iedere verwijzing naar wat in het verleden ligt, afwezig kan zijn, blijkt bijzonder duidelijk uit de volgende zin: bañjur yen běri yen arěp mapan turu kae, mujia, ñwun karo Gusti Allah men bapaq karo siěmboq diparini sugih (AMK 6, 9-12), en dan 's avonds als je gaat 
slapen weet je wel, dan moet je bidden en aan de Here God vragen dat $\mathrm{Hij}$ vader en moeder rijkdom schenkt.

V. Vertonen de hierboven genoemde betekenisonderscheidingen een duidelijk continue reeks, anders is het op het eerste gezicht gesteld met een ander gebruik van kae. Ik doel op het zgn. concessieve gebruik van dit woord. Enige gevallen zijn: bojo ayua kae, yen ana in romah

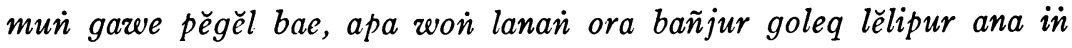
jaba? (OP 23, 4-6), ook al is de vrouw knap, als ze in huis alleen maar de man uit zijn humeur brengt, zal de man dan niet zijn troost buitenshuis gaan zoeken?; anaa in tanah Jawa kae, yen arěp mati, iya mati (AMK 20, 19-20), ook al ben je op Java, als je sterven moet, dan ga je toch. Het etiket: met concessieve betekenis is niet voldoende om dit gebruik van kae te beschrijven. Naast de zin: kĕsěla kae, iya měksa dilakoni (AMK 53, 2-1 v.o.), ook al is hij moe, toch doet hij het, is immers ook mogelijk: kěsěla, iya měksa dilakoni en ook deze zin heeft een concessieve waarde. Er is echter een belangrijk verschil. De zin zonder kae kan een hypothetisch geval stellen, maar behoeft zulks niet persé te doen: ook al zou hij vermoeid zijn, toch doet hij het. In de zin met kae is echter ieder element van veronderstelling afwezig. Beter zou men dus kunnen vertalen: zo vermoeid als hij is, toch doet hij het. Dit gebruik van $k a e$ is gebonden aan de aanwezigheid van een woord met suffix - $a$ in de groep waaraan kae is toegevoegd. Verder is ook hier kae weer gebonden aan de positie achter een woordgroep, al kan ook deze woordgroep wel eens uit één enkel woord bestaan.

De vraag, die thans gesteld moet worden luidt: bestaat er in het Javaans één woord kae of moeten er twee woorden $k a e$ gelijk van vorm maar met verschillende betekenis worden onderscheiden? Met andere woorden, men staat hier voor een identiteitsprobleem. Er was bij mij nl. wel enige reden om het bestaan van twee woorden $k a e$ voor mogelijk te houden. Immers, terwijl in de gevallen I-IV naast kae als krama uitsluitend mĕnika voorkomt, is het krama-aequivalent in geval V uitsluitend inatěn, c.q. měkatěn. Toen ik in interviews met informanten deze kwestie t.a.v. kae trachtte op te lossen o.a. door aan de hand van vroeger besproken gevallen waarin de identiteit evident was, hen gevoelig te maken voor het probleem, bleek mij, dat de gedachte aan de aanwezigheid van meer dan een woord hae zonder aarzeling verworpen werd. Neemt men nu voorshands aan, dat deze reactie voor het probleem een of twee woorden kae een zekere waarde heeft en dus pleit voor de opvatting dat er inderdaad in het Javaans slechts één woord kae voorkomt, dan rijst vervolgens de vraag of er wel continuiteit bestaat 
tussen de eerste vier betekenisonderscheidingen, die duidelijk een reeks vormen, met de vijfde, het zgn. concessieve kae. Mijn indruk is, gezien ook de reacties van informanten, dat in de bovenvermelde zinnen bojo ayua kae enz. en apa deq kowe dikěrah kucin kae, de beide woorden $k a e$ qua betekenis inderdaad dichter bij elkaar liggen dan de uiteenlopende Nederlandse vertalingen op het eerste gezicht doen vermoeden. Men zou om dit tot uitdrukking te brengen de eerst genoemde zin kunnen vertalen met: goed, de vrouw is mooi, laten we dat feit bekend veronderstellen ... Er is bovendien zoals reeds opgemerkt is een duidelijke syntactische overeenkomst tussen kae in het derde en het vierde en in het vijfde geval (nl. altijd aan het einde van een woordgroep). Ook Pigeaud blijkt in zijn woordenboek, gezien de wijze waarop hij het artikel kae heeft samengesteld, aan te nemen dat er slechts één woord kae bestaat. Dit alles in aanmerking nemend geloof ik wel te mogen concluderen tot het bestaan in het moderne standaard-Javaans van slechts één woord kae, waarin zich de hierboven besproken betekenisonderscheidingen aftekenen, ondanks de aanwezigheid van twee krama-aequivalenten.

Thans de betekenisonderscheidingen van $i k i$.

I. Het lijdt geen twijfel, dat $i k i$ altijd dient ter aanwijzing binnen de spreeksituatie van hetgeen zich bevindt of geacht wordt zich te bevinden in de directe omgeving, ruimtelijk zowel als temporeel, van de spreker. Enige gevallen: muga-muga kaya nono kuwi kěna kañgo tulada bansane aku korve kiyi (ER 70, 2, 13-14), moge dat kunnen dienen tot voorbeeld voor mensen zoals $\mathrm{jij}$ en $\mathrm{ik}$; ora Rein, kowe kiye, gěnahe kapriye? ( $\mathrm{K} 509,1,5-4$ v.o.), maar ( $\mathrm{Ga}$ ) rèng, wat is er met jou aan de hand (zegt Sĕmar als hij de als vrouw verklede Garèng

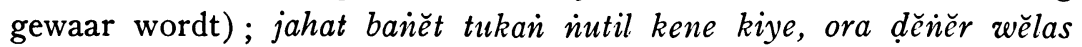
maraí uwon் (BD 71, 14-13 v.o.), erg gemeen zijn de zakkenrollers hier, zij kennen geen medelijden (jegens mensen).

II. Direct bij dit gebruik aansluitend komt $i k i$ voor in zinnen ter aanduiding van een direct volgende nieuwe ,message”, bijv. layaine unine kaya iki $(\mathrm{Sg})$, de brief, de inhoud ervan is aldus (waarop de weergave van de inhoud van de brief direct volgt). Dit $i k i$ staat in dergelijke zinnen in contrast met $i k u$. In een zin als layaine unine kaya $i k u$, de brief, de inhoud ervan is aldus, is de inhoud al in het voorafgaande weergegeven. Op precies dezelfde wijze worden, naar hieronder nog ter sprake komt, mĕrikene en mĕrikono gebruikt.

Minder bekend dan bovengenoemd gebruik van $i k i$ is het voorkomen 
van een anaforisch $k i$ dat niet identiek is met de reeds genoemde afkorting van $i k i$. Dit $k i$ wordt gebruikt wanneer de spreker extra de aandacht van de hoorder wil richten op hetgeen in de onmiddellijk voorafgaande woorden is gesteld. Het kan vaak met Ned. hoor of moet je weten worden weergegeven. Enige gevallen van gebruik: mas, aku saiki kĕndĕl ki (AMK 31, 21-22), heus hoor, mas, ik ben tegen-

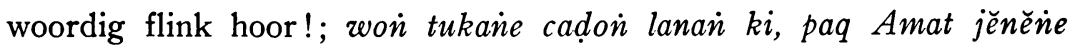
(AMK 31, 4-3 v.o.), want degene die ieder z'n eten geeft, is een man, moet je weten, pak Amat heet hij; lagi sapisan iki aku krunu ana pananan jrainkin; neq Batawi ora ana $k i$ (TB 60, 2, 28-29), dat is voor het eerst, dat ik hoor, dat er een snoeperij bestaat die djrangking heet, in Batavia heb je dat niet hoor!; daqtantan wani apa ora. Bu Mar ya tenis ki! (TB 72, 2, 3-2 v.o.), ik daag je uit, durf je of niet. Boe Mar speelt ook tennis, moet je weten! In geen van deze zinnen is dit $k i$ door $i k i$ of $k u z w i$ te vervangen. Dat identificatie met de afkorting $k i$ van $i k i$ bezwaarlijk is, blijkt uit het feit dat terwijl altijd voor $k i$ als afkorting $i k i$ te substitueren is, dit $k i$ echter nimmer door $i k i$ te vervangen is. Men kan verder constateren dat dit $k i$ uitsluitend optreedt aan het einde van een woordgroep en, zo deze uit meer dan één woord bestaat, altijd behoort bij de groep en niet dus uitsluitend bij het woord, dat direct aan $k i$ voorafgaat.

De vraag rijst of dit $k i$ hier, in het verband van de Javaanse pronomina thuishoort. Hoewel ik erken dat een zekere aarzeling gewettigd is, geloof ik toch dat $k i$ hier behandeld moet worden en wel om twee redenen. In de eerste plaats zijn duidelijk anaforische karakter. In de tweede plaats de even duidelijke parallellie van dit $k i$ met de vierde gebruikswijze van kae. Men zou kunnen zeggen: wat een betekenisonderscheiding is binnen de betekeniseenheid van kae, is hier gebonden aan een eigen klankvorm. Schematisch voorgesteld:

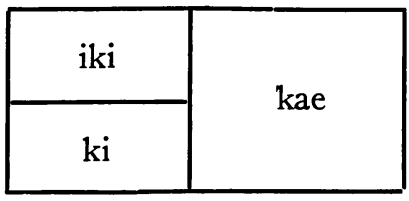

Tenslotte $i k u$ en $k u w i$, de normale vormen van de middelste horizontale rij. Hierbij zijn de volgende betekenisonderscheidingen vast te stellen : 
I. Iku en kuwi verwijzen naar de toegesproken persoon of wat tot hem direct in betrekking staat. Voorbeelden: Janga takon: lah oleh-olehe ěndi, mboq? ěmboqne: o, kuwi, aku ora tuku oleh-oleh (LBK 70, 1-2), Djangga vroeg: Zeg waar is wat je voor ons hebt meegebracht, moeder? Moeder : o, (vraag je) dat, ik heb niets gekocht voor jullie thuis; kowe kuwi pañcen iya won murain saraq won pindah omah bae katiq inarĕpake baqda (BD 137, 3-4), jij daar bent toch werkelijk een onmogelijke kerel, dat je waarachtig vlak voor Lebaran gaat verhuizen.

II. Daarnaast komen $i k u$ en kuwi voor ter aanwijzing binnen de spreeksituatie van wat temporeel of ruimtelijk niet direct tot de spreker behoort en wat dus niet voor verwijzing middels $i k i$ in aanmerking komt, bijv. yah, paqne kuwi le soq sěmbrana (BD 138, 12 v.o.), ach die man (van mij) telkens met zijn gekheid, zegt Maq Kamprèt tegen Nalagarèng als Pétroek Garèng er tussen neemt. In deze zin had zeer goed kiye kunnen staan i.p.v. kuwi, maar dan was naar Pétroek verwezen als iemand die zich bevindt in de onmiddellijke omgeving van de spreekster.

III. Het derde gebruik van $i k u$ en kuwi is het zgn. generieke gebruik: jaran iku of jaran kuwi kan betekenen: dat paard dat daar staat, het kan ook betekenen: het paard in het algemeen, paarden. Een enkel voorbeeld: saběněre manunsa iku ora ana gĕde, ora ana ciliq (BD 32, 18), feitelijk is wat de mens aangaat, de een niet meer dan de andere; neq cara priyayi kuwi, sin putri ana inarěp, sin kakun ana in buri (BD 154, 29-30), bij de prijaji's is het gewoonte, dat de vrouw voorop gaat, en de man volgt. Dit generieke gebruik van $i k u$ en $k u w i$ staat dicht bij het eerste gebruik. Iku wijst in beide gevallen op iets dat weliswaar onttrokken is aan de sfeer van de spreker, maar dat anderzijds toch ook positief binnen de spreeksituatie wordt gesteld. $\mathrm{Er}$ is hier een zekere parallellie met Ned. je dat ook in generiek gebruik kan voorkomen, bijv. je moet hier voor oppassen, d.w.z. niet de hoorder maar de mensen in het algemeen dienen dit te doen.

IV. Iku en kuwi kunnen ook terug verwijzen naar delen van de message zelf. $Z \mathrm{ij}$ vatten dan a.h.w. de inhoud van vaak zeer ingewikkelde woordgroepen nog eens in een woord samen. Regel is dat een pauze dan aan dit $i k u$ of $k u w i$ voorafgaat. Deze pauze kan in samenwerking met de intonatie distinctief functioneren, nl. wanneer $i k u$ of $k u w i$ ook een groep zou kunnen vormen met het woord van de woordgroep dat onmiddellijk aan $i k u$ of kuwi voorafgaat. Zo bijv. ngitiq bocah kuwi ora patut. Wordt na bocah een pauze gemaakt, 
wordt de stijging van de intonatie afgebroken voor kuwi en stijgt na de pauze de intonatie opnieuw, dan is bedoeld: kinderen slaan, dat geeft geen pas (intonatiepatroon: ). Stijgt de intonatie ononderbroken tot en met kuzvi, dan betekent de zin: díe jongen(s) slaan, geeft geen pas (intonatiepatroon: ). Voorbeelden van dit bekende anaforische gebruik zijn: in kuta dianaqake gěmintĕ, kurei karĕpe arěp mbĕciqake kaanane in kuța kono (BD 169, 4-5), dat men de steden tot gemeenten maakt, de bedoeling ervan is om de toestanden in de steden te verbeteren; ... neq won lanai sin mlaku ana inarěp, kuzvi didělě̀n raq ora pantěs... (BD 154, 27-28), als de man voorop gaat, dat feit, als men dat ziet, dan is dat toch niet

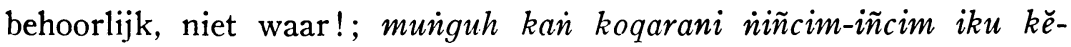
priye? (SK 74, 5 v.o.), wat betreft hetgeen jij bedreigen noemt, hoe zit dat? Vaak is in het Ned. dit $i k u$ goed te vertalen met: dit feit, deze omstandigheid nu. Hoe gecompliceerd de gevallen kunnen zijn, kan blijken uit de volgende zin: nagara nanaqake pranatan milih warga

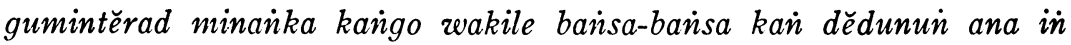
gěmintĕ kono, $k u$ wi krĕsane nagara siji-sijine wakil supaya bisaa migateqake ... apa sï dadi... kaprĕluwane bansane dewe-dewe mau (BD 168, 22-26), dat het gouvernement een regeling in het leven roept voor de verkiezing van gemeenteraadsleden als vertegenwoordigers van de verschillende bevolkingsgroepen die in de gemeente woonachtig zijn, daarvan is de bedoeling van het gouvernement dat iedere vertegenwoordiger zal kunnen behartigen wat de belangen zijn van iedere bevolkingsgroep afzonderlijk.

V. Hierbij sluit zich aan het gebruik van $i k u$ en kuwi dat wij hierboven reeds in contrast met $i k i$ noemden. $I k u$ en kuwi kunnen niet alleen terug verwijzen naar een deel van de zin waarin zij zelf voorkomen, maar ook naar de zin die onmiddellijk voorafgaat aan de zin waarin zij voorkomen, bijv. kuzei unine layaine, aldus de inhoud van de brief. Dit gebruik van $i k u$ en $k u w i$ is zeer frequent in verbinding met de woorden nalika en kain, krama inkain. Nalika iku betekent toen, op dat tijdstip waarop het in de voorafgaande zin of zinnen medegedeelde plaats vond: swara lan tandañe rainga Kuwata nalika kuwi mĕdeni baìĕt, těměnan, ndadeqake girise won sin alaku cidra (BD 28, 27-28), de stem en de houding van rangga Kuwata waren op dat ogenblik (toen hij de voorafgaande woorden sprak) zeer angstaanjagend, werkelijk, zij wekten bij de misdadigers hevige angst op; deq kowe dadi nanten aku ora jagon, awit nalika iku aku nuju lara bañĕt (Sg), toen jij trouwde, was ik niet op het feest, omdat ik op dat tijdstip 


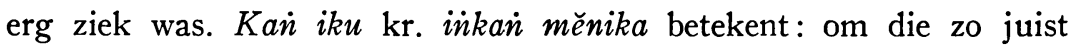
genoemde omstandigheid, en om die reden. Gevallen van gebruik: bapaq, kula botěn pisan-pisan binah, bilih bapaq inantos maingih kasu-

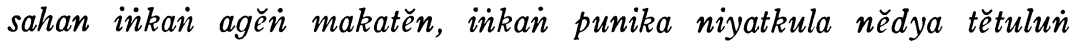
datěr bapaq (MMTj I, 31, 14-16), vader, ik ben helemaal niet verheugd, dat $\mathbf{u}$ zulke grote moeilijkheden ondervindt, en daarom is het mijn voornemen $\mathrm{u}$ te helpen; katrĕsnanku wiwit ciliq $\dot{n} a n t i$ sĕprene $i k i$, ora kĕna taqsabili... rupamu saya katon ayu... kan் iku rehnin atiku

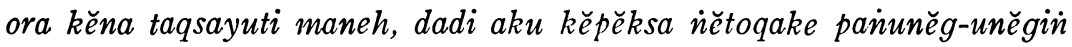
atiku (GW I, 15, 9-16), aan mijn liefde, die ik van jongs af an tot nu toe (voor je koester), kan ik niet (meer) weerstand bieden, je werd (voor mij) hoe langer hoe lieflijker ... en daarom, omdat mijn hart niet meer kan worden bedwongen, moet ik wel uiting geven aan wat mijn hart vervult.

Overzien wij thans de gebruikswijzen van de drie pronomina, dan blijkt duidelijk, dat $i k i$ altijd wijst naar de spreker zelf of wat direct tot diens sfeer behoort, $i k u$ in het algemeen wijst naar wat in de spreeksituatie niet voor aanwijzing door $i k i$ in aanmerking komt, en verwijzen kàn naar de hoorder, maar zulks niet beslist behoeft te doen, terwijl kae altijd wijst naar wat buiten de spreeksituatie ligt en geen betrekking heeft op de aan de spraakhandeling deelnemende personen.

$\mathrm{Na}$ deze semantische beschouwing volgt thans de bepaling van de morfologische valentie van deze pronomina. De mogelijkheden zijn zoals trouwens bij alle pronomina demonstrativa, naar reeds hierboven is medegedeeld, gering. Bovendien zijn zij niet geheel gelijk voor de pronomina van verschillende horizontale rijen. Mogelijk is alleen: 1. suffigering van $-a: i k i a, 2$. suffigering van $-n e$ : ikine, 3 . verdubbeling, 4. verdubbeling met zgn. vocaalvariatie : $i k \grave{a}-i k i, 5$. prefigering van $s a q-$ : saqiki.

Vormen met suffix - $a$ komen uitsluitend voor in zinnen van het volgende type: kuwia kae, neq kĕpětuq ana in dalan, měsți ñaw'ati, paḍa bae karo liyane (PPB 8, 5-7), zelfs die (jongen), als hij mij op straat zou tegenkomen, zou hij zeker naar me gooien, net zo als de anderen; nango pacul ikua, kěna wae ta, won் iya pacul-paculku dewe (SIR), o,ok al gebruik ik die patjoel dan mag dat, want het is immers mijn eigen patjoel.27

\footnotetext{
27 Aandacht verdient de verdubbeling pacul-paculku met achter gevoegd dewe. Men heeft hier te maken met een vaste constructie, cf. y'a ben, izwaq lehe aweh ibu-ibuku dewe koq hara (KA 6, 1), goed, laat maar, dat vlees heb ik notabene van mijn eigen moeder gekregen.
} 
Door suffigering van -ne vindt transpositie naar de woordsoort der substantiva plaats, naar uit de volgende gevallen van gebruik blijkt: ikine lo sin rusaq (SIR), kijk, dit er van is kapot; bapaqmu olehe luna kĕsusu, lali ikine, gělis susulna (Sg), je vader is haastig weggegaan, dit van hem heeft hij vergeten, breng het hem gauw achterna; kiyene won iki tiba $(\mathrm{Sj})$, dit van deze man is gevallen. In teksten komen -ne-vormen zelden voor. Van ikune en kaene bezit ik geen gevallen van gebruik. Volgens mijn informanten is het evenwel denkbaar dat zij voorkomen, al zal het niet veelvuldig zijn. Nader onderzoek op dit punt is gewenst.

Verdubbeling doet zich alleen voor bij kae: yen kowe do $\dot{n}$ ngarap apa wae, aja mikir kae-kae, mundaq ora apiq dadine (Sg), waar je ook mee bezig bent, denk niet aan allerlei andere dingen, anders bereik je geen goed resultaat; woǹ kuwi najan duwe barañ rupa-rupa, mĕksa kĕpeniin kae-kae sin durun ana (Sg), ook al bezit de mens van allerlei, toch blijft hij allerlei begeren wat hij nog niet heeft. Over gevallen van gebruik in teksten beschik ik niet; niettemin is het m.i. zeker dat deze verdubbeling zich in mondeling taalgebruik regelmatig voordoet.

Verdubbeling met vocaalvariatie komt bij alle vormen (maar niet bij de verkorte) regelmatig voor, bijv. kiye, kiye, bu, engal priksani $(\mathrm{Sj})$, hier, hier, moeder, kom eens gauw kijken, waarop de moeder zuchtend zegt: bocah koq kiya-kiye wae $(\mathrm{Sj})$, wat zit dit kind toch maar steeds kive te roepen. Zo ook: bocah kurer rewel, ñjaluq ditukoqake dolanan, muni ika-iki karo nudini sin dikarĕpake (Sg), dat kind is lastig, het vraagt maar dat men speelgoed voor hem koopt, aldoor maar $i k i$, $i k i$ zeggend, al wijzend op wat hij wil hebben.

Combinatie van de twee laatstgenoemde formaties is mogelijk: muni ika-ikia kae, bapaqne mĕksa ora inrewes ( $\mathrm{Sg}$ ), ook al roept hij telkens $i k i, i k i$, toch stoort zijn vader zich er niet aan.

In de prefigering met saq- zal men, gezien de betekenis aan deze vormen eigen, een transpositieprocédé en wel naar de woordsoort van de telwoorden hebben te zien. Gevallen van gebruik in teksten heb ik niet gevonden. In spreektaal komen zij wel voor, bijv. gĕdene saqiki, de grootte er van is zo groot als dit (lett. is één dit). Duidelijk is dit saqiki parallel aan het hierboven besproken saqaku. Op dezelfde wijze komt saqiku voor; of saqkae kan voorkomen, is mij niet bekend.

Met dit saqiki dient niet verward te worden het zeer frequent voorkomende saqiki of saiki, madya saniki, krama saměnika (geschreven meestal: sapunika), nu, tegenwoordig. Niet alleen is er een duidelijk betekenisverschil maar er is ook vormverschil. Saqiki, zo groot als dit, 
heeft altijd de stembandklapper tussen de eerste twee vocalen, saiki, nu, komt zonder betekenisverschil soms met soms zonder stembandklapper voor; dit wordt gereflecteerd in de spelling met Javaanse karakters (soms saiki, soms sakiki, madya sakniki). Bovendien komt naast saiki, nu, geen saiku o.i.d. voor. Naast dit $s a(q) i k i$, nu, staat $s a(q)$ ikine, dat door enkele grammatica's en door Gericke-Roorda wel vermeld wordt, maar semantisch niet nader ten opzichte van $s a(q) i k i$ wordt bepaald. $S a(q) i k i n e$ verschilt van $s a(q) i k i$ in de eerste plaats doordat het de betekenis kan hebben van: nu eerst, nu eindelijk. Zo bijv. saikine kĕcandaq, nu eindelijk heb ik je te pakken, zit je vast, tegenover het vlakke, neutrale: saiki kĕcandaq.

Duidelijk blijkt ook deze betekenisonderscheiding in saikine uit de volgende zin afkomstig uit een Pétroek-Garèng-dialoog: $e$, irěti aku

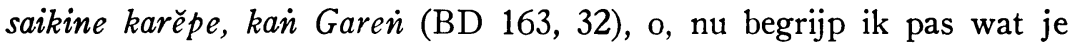
bedoelt, (broer) Garèng. In de tweede plaats heeft $s a(q) i k i$ in vergelijking tot $s a(q) i k i n e$ een ruimere betekenis, het is een woord dat het heden aanduidt, onverschillig of dit heden slechts dit moment van de spreker nu dan wel een meer uitgestrekte periode aangeeft: de tegenwoordige tijd waarin de spreker zich bevindt. Wil men bepaald aangeven: dit moment nu, dan wordt $i k i$ of kiyi achter gevoegd: $s a(q) i k i$ $i k i, s a(q) i k i$ kiye (madya saniki niki, krama saměnika mĕnika).

Is er sprake van contrast bijv. door een voorafgaand of volgend biyen of besuq, dan is sa(q)ikine uitgesloten. Zo kan bijv. in zinnen: lha saiki wis dina Lěbaran, (TB 177, 1, 1), ha, thans is het Lĕbaran

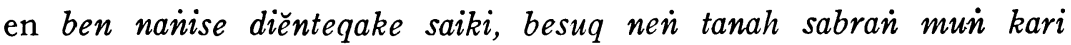
nguyune (AMK 23, 4-5), laat (haar) maar, laat ze nu maar uithuilen, later aan de overwal blijft (voor haar) slechts lachen over, saiki niet door saikine vervangen worden.

In het algemeen lijkt $s a(q) i k i$ tegenover $s a(q) i k i n e$ de niet-gekenmerkte vorm, met een vlakke, onnadrukkelijke betekenis. Zo is in de emotionele zin: mara, kajaba pankat saradadu karo mantrus, paikat apa, hara, sin saikine ora dileboni in won wadon? (BD 163, 27-29), zeg eens, behalve de functie van soldaat of matroos, welke functie, zeg, worden heden ten dage (,,vandaag de dag”) niet door vrouwen bekleed?, saikine geheel op z'n plaats.

Behalve de madya-vorm sa(q)nikine komt in sommige teksten ook sapunikane voor, bijv. kula lajĕ̀n dipun-suduqi kalih pun Janaka, kula mlajĕn, sapunikane kula taksih dipun-bujun (L. Th. Mayer, Vier en twintig schetsen van wajangverhalen, 1883, p. 221, 11-12), ik werd herhaaldelijk gestoken door Djanaka, ik nam de vlucht, nú nog word 
ik als maar door hem nagezet. Sapunikanipun is de normale kramavorm: Ingih makatěn naq, naniin sapunikanipun dados murid calon dukun bayi (DjP 65,9-10), inderdaad jongen, maar ze is tegenwoordig leerlingkinderverpleegster.

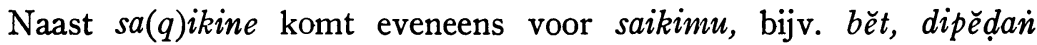
gulune karo cĕlațu: mati kowe saikimu (KA 59, 24-25), rang, hij gaf hem een slag in zijn hals zeggend: $n u$ is het subiet met je gedaan, nu is je laatste uur geslagen! Hier zou vervanging van saikimu door saiki, de zin veel van zijn expressieve kracht ontnemen. Uiteraard komt saikia bijv. in verbinding met kae voor: saikia kae, iya isih ana siji loro, naiiin ora kaya deq isih swargi (SR 58/59), goed, zelfs tegenwoordig zijn er inderdaad nog wel een of twee, maar het is toch niet zo als ten tijde dat Zijne Hoogheid nog leefde.

Zoals reeds hierboven bij de algemene karakteristiek is opgemerkt, zijn er slechts twee combinatiemogelijkheden van deze pronomina onderling, nl. $i k i-i k u$ en $i k a ́-i k i$, niet te verwarren met $i k a ̀-i k i$, de verdubbeling met klankvariatie die wij reeds besproken hebben. Zo kan bijv. in de zin měnawa anaqe ñjaluq iki-iku, měsți dituruti (Sg), als het kind om dit of dat vraagt, dan krijgt hij zeker zijn zin, inplaats van $i k i-i k u$ ook zeer goed $i k a ́-i k i$ staan. Het verschil tussen beide composita is gelegen in het feit dat $i k i$-iku meer naar een beperkte, in de situatie van het spreken voorhanden zijnde verscheidenheid verwijst, iká-iki daarentegen ook wijst op alle mogelijke dingen (speelgoed bijv. in dit geval) ook buiten de situatie van het ogenblik gelegen. Deze combinaties kunnen zelf weer gecombineerd worden met het suffix -ne, zo bijv. mula uga kĕpenaq bañet tanduqe Hartati, ora ana ika-ikine, malah Hartati bisa nanduqake rasa wĕlase maraì priyayi sakaliyan mau (DjP $55,6-8)$, daarom was ze volkomen op haar gemak, er was niet dit of dat (d.w.z. geen enkel) gevoel van gêne, ja zelfs kon ze medelijden betonen jegens die mijnheer en mevrouw.

Ten aanzien van de valentie zullen wij ons, gezien het feit dat het valentie-onderzoek van het Javaans nog nauwelijks begonnen is, tot enkele opmerkingen beperken, die een voorlopig karakter dragen. Het volledigst zullen we zijn over de mogelijkheden van groepsvorming van de pronomina onderling.

De pronomina van de $i k i$-serie kunnen naar bekend is, deel uitmaken van zeer verschillende woordgroepen.

In de eerste plaats maken zij deel uit van verschillende typen van onderwerp-gezegde groepen: bijv. iki wone, dit is de man; iki bĕnĕr, dit is juist, of met inversie lěrěs měnika, juist is dat. 
In de tweede plaats kunnen zij in substantief-groepen en in verbinding met eigennamen voorkomen; voor een dergelijke groep is het een absolute eis dat het pronomen het substantief volgt, waarbij het echter niet noodzakelijk is dat het er onmiddellijk op volgt: Maryati $i k u$, die Maryati, cf. w'on $i k u$, die mensen, met woó tělu $i k u$, die drie mensen.

In de derde plaats komen de pronomina van de $i k i$-serie veelvuldig voor in combinatie met exclamatieve woorden die de aandacht van de spreker op een bepaald element van de situatie richten. Bekend zijn zo de combinaties met $l o$, kijk, en met hla 28 en lah (bijv. iki lo, kijk hier is het, voici!; kae lo, voilà ; hla kuzir, nu, daar heb je het, dat veel emotioneler is dan lah kurer).

In de vierde plaats vindt regelmatig verbinding plaats met tijdaanduidende woorden, waarvan nader onderzoek nog moet uitmaken of en in hoeverre zij een of meer morfologische categorieën vormen. Daarbij kan men in het algemeen opmerken, dat woorden die het heden aanduiden, zoals bijv. saiki en samainke gecombineerd kunnen worden met $i k i$, woorden die het verleden aanduiden veelvuldig met $k a e$, bijv. (deq) biyen kae, toentertijd.

In de vijfde plaats kan vooral $i k u$ gecombineerd worden met verba, waardoor de groep een zelfde valentie krijgt als de groep substantivum

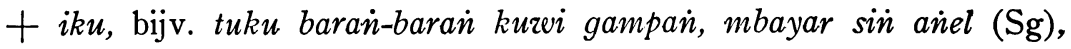
allerlei kopen is gemakkelijk, betálen is moeilijk; ñěkarakĕn punika botěn gampil, (een prozastuk) omzetten in těmbang (dat) is niet gemakkelijk. In dergelijke gevallen wordt altijd de generieke betekenisonderscheiding van $i k u$ geactueerd.

Wat de verbindingsmogelijkheden binnen de woordsoort der pronomina aangaat, zij kunnen met de pronomina personalia groepen vormen, waarbij de $i k i$-serie altijd achter de personalia komt; slechts telwoorden en locale demonstrativa kunnen de pronomina personalia van de $i k i$ serie scheiden, cf $a k u i k i$, kozve $i k u$, deweqe kae, maar bijv. aku kene $i k i$, aku tělu $i k i$, of ook aku tělu kene $i k i$, wij drieën hier. Het meest frequent zijn de groepen van pronomina uit dezelfde horizontale rij, er zijn echter ook andere combinaties mogelijk, terwijl weer andere zijn uitgesloten. Iki kan behalve met $a k u$, ook met kowe en deweqe een groep vormen. Iku slechts met kowe en deweqe, kae uiteraard slechts met deweqe. In schema gebracht:

28 Zoals zovele exclamaties heeft $h l a$ een anomale structuur; de schrijfwijze $h l$ staat voor een eigenaardige geaspireerde $l$ die overigens in het Javaans in geen enkel woord voorkomt. Ook de à-variant van het A-foneem is anomaal. 


\begin{tabular}{|l|c|c|c|}
\cline { 2 - 4 } \multicolumn{1}{c|}{} & $\mathrm{iki}$ & $\mathrm{iku}$ & $\mathrm{kae}$ \\
\hline $\mathrm{aku}$ & + & - & - \\
\hline kowe & + & + & - \\
\hline deweqe & + & + & + \\
\hline
\end{tabular}

Met het compositum aku-kowe kan zowel $i k i$ als $i k u$ een groep vormen, kae uiteraard niet.

Met de pronomina interrogativa et indefinita kunnen zij naar te begrijpen valt niet direct verbonden worden, behoudens in bepaalde cnderwerp-gezegde groepen : sapa kurir, wie is dat! apa iki, wat is dit?

Tenslotte komen de pronomina van de $i k i$-serie voor in enige vaste verbindingen met andere woorden; zo komt uitsluitend $i k u$ voor in combinatie met iya, mau alleen met kae.

\section{De kene-serie}

Daar verkorting bij de locale demonstrativa niet optreedt en er geen afzonderlijke madya-vormen voorkomen, bevat deze serie slechts 6 vormen. Het bij Pigeaud als gewestelijk krama bij kene, kono en kana vermelde mriki, mriku en mrika was aan onze informanten onbekend. In teksten ben ik hen niet tegengekomen.

\begin{tabular}{|l|l|}
\hline Ngoko & Krama \\
\hline kene & nriki \\
kono & ṅriku \\
kana & nrika \\
\hline
\end{tabular}

In het algemeen is het onderscheid tussen kene, kono en kana parallel aan dat wat tussen $i k i$, $i k u$ en $i k a$ bestaat. Kene betekent: hier bij de spreker van de uiting, waarin kene vookomt, kono daar bij de hoorder van de uiting, waarin kono voorkomt, kana daar ginds buiten de spreeksituatie. Voorbeelden: in tanahe dewe kene iki (BD 143, 24), in dit eigen land hier; in pulo kono kuzi mau (BD 144, 4), op dat eiland daar; běciqe měñana kantoran kana (BD 128, 33), laten we maar liever gaan naar mijn werkkamer daarginds. Duidelijk is het verschil tussen 
kene en kono enerzijds en kana anderzijds: yen koqgoleqi kene kono wae mansa bisaa oleh; sin ana kana lo, in kuṭa sin gĕde upamane Surabaya (Sg), als je het alleen maar hier of daar in de omgeving zoekt, zul je het onmogelijk vinden; waar het wel is, dat is ginds, in een grote stad als Soerabaja. Bekend is eveneens dat in de spreektaal kene en kono kunnen staan resp. voor aku en kozve, terwijl kana kan betekenen: hij daar; zo bijv.: neq ianti kaume wĕruh kene pada main brij, raq iya murin̈-murin tĕměnan (BD 139, 4-3 v.o.), als het zo ver komt dat de kaum ziet dat wij aan het bridgen zijn, dan is hij natuurlijk echt verstoord; we, hla ora gĕnah, kono sin riajaq, těka kene sin dikon mbayari (BD 154, 14-15), nou, dat is toch geen manier, híj nodigt uit, maar ik moet waarachtig betalen; kene arĕp marani, kana koq ńlunani $(\mathrm{Sj})$, ik wil er naar toe, en nu wil hij er waarachtig vandaan! Bij de corresponderende krama-vormen is dit gebruik niet mogelijk.

Verder komen kene, kono en kana veelvuldig voor in zinnen waarin een verzoek wordt gedaan of een bevel gegeven. Voorbeelden: ělo koq běni-běni ... kene mlěbu kene ... ana prẹlu apa? (AMK 49, 6-7), he, zo laat nog... hier, kom binnen, hier, ... wat is er? (tegen een late onverwachte bezoeker); boḍo kowe kuwr, Mblĕg, kene taqtulupake (BG I, 17, 18), je bent dom, (Goe)mblĕg, hier, ik zal eens voor je met de blaaspijp schieten; kono lingiha dewe in kursi, sibu kĕsĕl koqlendoti $(\mathrm{Sg})$, daar, ga nu eens zelf in een stoel zitten, moeder is moe van dat tegen haar aanhangen van jou; koq siěmboq ora sugih, ya gene ta? $Y a$ émbuh, takona derve kana (AMK 5, 22-24), hè, is moeder niet rijk, hoe komt dat toch? Dat weet ik heus niet, vraag het haar zelf maar, daarginds ; wis kana turu, Subiyah, sesuq neq kawanan (WG 28, $7-6$ v.o.), genoeg, ga nu maar slapen, Subiyah, anders word je morgen nog te laat wakker. Duidelijk is het waarom in deze zinnen in het ene geval kene, in het tweede kono, in het derde kana wordt gebezigd. Ook in deze zinnen richt kene de attentie van de hoorder op de spreker, kono op de hoorder zelf, terwijl kana verwijst naar iets dat nog buiten de spreeksituatie ligt. In dit soort zinnen staan deze pronomina als regel onverbonden met andere woorden aan het begin of het eind van de zin. Slechts een woord als het de discussie afsluitende wis kan aan hen voorafgaan.

Speciale vermelding verdient voorts het gebruik van kono na tijdsaanduidingen in de betekenis van ongeveer, omtrent, in de buurt, bijv. iya sesuq-sesuq kono yen koberr ( $\mathrm{T} \mathrm{jB} \mathrm{I} 38,3-5)$, ja later eens als ik tijd heb; mboqmĕnawa, ěmben-е̌mben kono gamělan P̣ayaq, Papureah. jațilan ... paḍa dilěboqake raḍiyo ( $\mathrm{K} 455,1,9-4$ v.o.), misschien, 
later in de toekomst, worden de Dajakse, de Papoease gamĕlan, de djatilan wel allemaal voor de radio ten gehore gebracht. Dit gebruik van kono vindt een zekere parallel in nono, dat eveneens achter tijdsaanduidingen voorkomt: matura zrae, suq ëmben niono, ora susah dipundut, bakal taqaturake dewe (BD 131, 11-12), zeg maar overmorgen, naar ik vermoed, 't behoeft niet gehaald te worden, ik zal 't zelf brengen. $\mathrm{Er}$ is evenwel verschil in betekenis; kono staat achter vage, onbepaalde tijdsaanduidingen, nono na woorden die een precies bepaald tijdstip aangeven; kono en nono zijn dan ook in bovengenoemde zin niet voor elkaar te substitueren. Het is de vraag of dit nono wel enig verband onderhoudt met ṅono $=$ mĕńkono. Wij komen bij de behandeling van de mĕnkene-serie hier nog op terug. Ook de krama-vorm iriku komt op deze wijze voor, bijv. ëmben-ěmben inriku, yen sěla damĕlan, kula datěn griya sampeyan (Sg), overmorgen of zo, als ik vrij heb, kom ik bij $\mathrm{u}$ thuis.

De volgende combinaties van de pronomina locativa zijn mogelijk: $1^{\circ}$ kene-kono (krama: inriki-íriku), $2^{\circ}$ kana-kene (krama: irika-inriki). Voorbeelden: saiki jaman kamajuan, zus, anane bĕbasan: kĕbo manut gudel, wis tumindaq in kana-kene (MMTj I 27, 18-19), nu is het de tijd van de vooruitgang, zus, het spreekwoord: de (buffel)koe volgt het kalf, geldt tegenwoordig overal (ginds en hier); wah kana-kene katon ijo riyo-riyo (OOA 55, 14-15), o, overal zag het er fris groen uit. Het verschil in betekenis van dit kana-kene met kene-kono komt duidelijk uit in de volgende zin: kowe dolana kene-kono wae, aja adoh-adoh, yen taqundan ben ndain tĕka (Sg), ga maar hier of daar spelen, maar niet te ver, opdat als ik je roep, je gauw komt.

Op basis van kene, kono en kana zijn vier, misschien vijf morfologische procédé's mogelijk: 1 . suffigering van $-a, 2$. suffigering van $-n e$ (krama: -nipun), 3. verdubbeling, 4. verdubbeling met $\mathrm{zgn}$. vocaalvariatie, 5. suffigering van -ake 29 (krama: akěn). Enige gevallen van gebruik:

Ad 1: ana kenea kae aku nuju ribut ora koběr n்ulatake woǹ lizeat $(\mathrm{Sj})$, ook al was ik hier, ik was toevallig druk in de weer en had geen tijd om op de voorbijgangers te letten.

Ad 2: kenene, lo sin kěna (SIR), hier, zeg ben ik geraakt; kenene ora mizeriti ala, koq konone nantain najaq kěrĕ̀ian $(\mathrm{Sg})$, deze kant (= wij

29 De procédé's worden hier slechts aangeduid met een van de alternanten; een volledige vermelding van alle alternanten (bij -ake dus bijv. -qake en -qakěn met vocaalwisseling) kan achterwege blijven omdat deze reeds vroeger beschreven zijn en algemeen bekend mogen worden geacht.

Verh. dl. XXX 
hier) is niet begonnen met hen iets kwaads te doen, en daar gaat notabene de andere kant (= zij daar) ons uitdagen om te vechten; dikira lupute bansa Tion Hwa, iya won் konone, mulane iya měnĕn் bae (AMK 38, 3-2 v.o.), hij dacht: zoal niet een Chinees, dan toch zeker iemand van daar (nl. uit de Lampongs), daarom zweeg hij maar; laikun asri

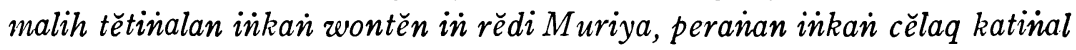

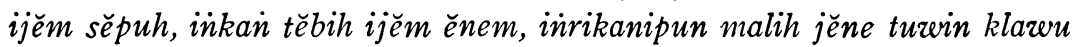
(PTT I 28, 4 -6), nog fraaier was het gezicht op de Moerja, de dichtbij gelegen delen zagen er donkergroen uit, wat ver af was, was lichtgroen, nog verder weg was het geel en grijs. In deze zinnen zouden eveneens de pronominale vormen zonder suffix hebben kunnen staan. De vormen met suffix zijn echter emfatisch in vergelijking tot de suffixloze vormen. Bekend is speciaal het gebruik van nein kanane voor: daarginds, in de wereld van de droom, bijv. ... sababe aku iya nimpi; nei kanane ali-aliku iki kĕcémplun sumur... (WG 100, 11-12), ... omdat ik ook gedroomd heb; daar ginds in mijn droom viel deze ring van mij in de put.

Ad 3: wis lumrahe woń arĕp maju ya kudu mabur těkan kana-kana, masa mun arĕp inuṇderr ana iii desa bae (TB 68, 2, 12-10 v.o.), het is normaal dat mensen die vooruit willen, bereid moeten zijn overal heen uit te vliegen, het is toch uitgesloten dat ze maar altijd in het dorp blijven hokken; běnanipun banawi Sirayu... ugi damĕl gugupipun para tětiyain iñrika-inrika (PPT I 16, 10-7 v.o.), de overstroming van de Sirajoe bracht ook de mensen overal tot ver in het rond in verwarring.

Ad 4: sin duwe omah sasat tanpa leren muni kenà-kene, akon lunguh dayoh sin pada těka $(\mathrm{Sg})$, de gastheer zei practisch onophoudelijk : „hier, hier", al de aankomende gasten verzoekend plaats te willen nemen.

Ad 5: onze gegevens betreffende transpositie naar de verba middels suffigering van -ake zijn zeer beperkt. In de 23 schetsen van wajangverhalen die door te Mechelen zijn uitgegeven, komt eenmaal (p. 318, 3-4) keneqna voor, de imperatief die bij dikeneqake hoort, met de betekenis van: geef hier! Ik acht het echter geenszins uitgesloten dat deze transpositiemogelijkheid zich geregelder voordoet dan de schaarse gevallen uit teksten doen vermoeden.

De syntactische valentie van kene enz. is in grote lijnen dezelfde als die van de pronomina van de $i k i$-serie. Zeer frequent is de groep met de praepositie in (in kene, hier, op deze plaats, in kono, daar bij jou, in kana, daar ginds). Bij de krama-vormen klinken geen twee velare nasalen na elkaar, men hoort er slechts één; niet $i \dot{n}$-inriku dus, maar altijd inriku; bij verdubbeling: inrika-ñrika, overal ginds. 
Opgemerkt dient te worden dat speciaal de groep in kono niet alleen locale maar ook temporele betekenis kan hebben: ... in kono lagi gělěm goleq panupajizwa in babagan pangaotan (ER 94, 2, 31-33), toen eerst wilde hij zijn levensonderhoud zoeken in het bedrijfsleven; in kono bañjur didadeqake patih lan dipeq mantu (OOA 105, 6-5 v.o.), toen werd hij vervolgens door hem tot patih verheven en tot schoonzoon genomen; anaqe lara ... lara - lara - inanti dadi lan patine; in kono Martin ěnteq paiarěp-arĕpe (K 1249, 2, 12-14) zijn kind was ziek ziek - (steeds maar) ziek, tot het zelfs stierf; toen was het (zo ver) dat Martin al zijn hoop verloren had.

\section{De mĕnkene-serie}

Deze serie omvat de volgende vormen:

\begin{tabular}{|c|c|c|c|}
\hline \multicolumn{2}{|c|}{$\mathrm{Ng}$ oko } & $\mathrm{Krama}$ & Madya \\
\hline II & verkort & II & verkort \\
\hline mènkene - nene & ene & & měketěn - netěn ketěn ) \\
\hline měńkono - ṅono & no (mono?) & mĕkatěn — natĕn & měkotěn - notěn kotĕn $\}$ tĕn \\
\hline měńkana - ṅana & (mana?) & & mĕkatěn — natěn ） \\
\hline
\end{tabular}

Het eerste wat bij deze serie opvalt is dat men niet met één, maar met twee parallelle reeksen te maken heeft. Het enige betekenisverschil tussen hen is dat reeks I een iets formeler karakter draagt dan de tweede en in verzorgde spreektaal en in geschreven taal overweegt. In vlotte dagelijkse spreektaal daarentegen zal de tweede serie vooral voorkomen, al wil dit niet zeggen dat met name mĕnkene en měrikono dan in het geheel niet gebruikt zullen worden. Parallel aan wat we bij de $i k i$-serie constateerden zijn měkatěn en natěn de krama-vormen die tot de standaardtaal gerekend worden en zijn měketěn, měkotěn en ìetěn, notěn dialectische krama-vormen; zij worden ook gehanteerd in het zgn. madya. Behalve deze 12 vormen komen ook nog enige verkorte vormen voor: ene en no zijn verkortingen van inene, resp. nono; waar ze voorkomen kunnen ze steeds door deze twee laatste vormen worden vervangen zonder betekenisverschil. Aan hen en aan mono en mana zal hieronder nog nader aandacht worden geschonken. Ketěn en kotěn zijn 
verkortingen van měketěn en měkotěn; men vindt hen in madya en in dialectisch krama; hetzelfde geldt voor het dialectische tĕn, dat formeel zowel een verdere verkorting van de vormen van serie II als een verdere verkorting van ketěn of kotěn kan zijn.

Het betekenisverschil tussen de drie horizontale rijen loopt in het algemeen parallel met dat tussen $i k i$, $i k u$ en $k a e$. Op een aantal punten is de parallellie bijzonder treffend, naar hieronder nog blijken zal.

Më̀nkene betekent zo als dit hier, aldus, zoals de spreker van de zin waarin mĕnkene voorkomt, bij zich zelf aanwijst: klambi kaya mĕnkene (of n்ene) yen koqrĕgani sěringit mansa payua (Sg), zo'n baadje als dit, als je er een rijksdaalder voor vraagt, doe je het nooit van de hand (situatie bijv. spreker heeft het baadje in de hand ter beoordeling). Hierbij sluit zich aan het zeer frequente gebruik van měnkene ter verwijzing naar wat komt, bijv. ijabe pananten sin sarana dipadani in obor

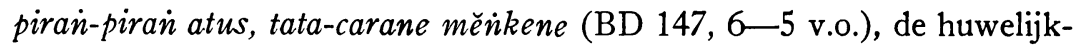
sluiting die plaats vond bij het licht van (ettelijke) honderden fakkels, het ceremoniëel ervan was aldus... (en dan volgt daarop de uiteenzetting van de spreker hoe het was); crita měnkene iki ora bĕciq dirunoqake in bocah $(\mathrm{Sg})$, zo'n verhaal als dit is niet geschikt om door kinderen te worden aangehoord. Het verhaal moet dan nog worden verteld. Had er mënkono gestaan, dan was het verhaal gedaan en had men te maken met een observatie achteraf. Het lijkt overbodig om deze twee betekenisonderscheidingen van mènkene uitvoerig toe te lichten. Iedere tekst bevat legio gevallen van gebruik van mënkene met deze twee betekenisonderscheidingen. Ik beperk mij tot het volgende duidelijke geval: ora měnikono kañmas, měnkene dadine binun்ku... (SS 157, 15-16), neen, zo was het niet (zoals jij hebt uiteengezet), broer, zo (als nu volgt) is mijn verwarring ontstaan.

Ménkono, zoals dat, zoals dat zo juist is uiteengezet, zulk een, dient behalve om terug te wijzen naar feiten of omstandigheden die aan de zin, waarin měnkkono voorkomt, zijn voorafgegaan, ook in het algemeen om te wijzen naar datgene waarop niet door middel van mĕnkene en měnikana kan worden verwezen. D.w.z. het wordt gebruikt zodra er niet naar iets in de onmiddellijke omgeving van de spreker of naar iets wat onmiddellijk met hem in verband staat, wordt gewezen en zodra het niet gaat om een modale verwijzing naar iets wat bepaald buiten de spreeksituatie ligt of geacht wordt te liggen, zo bijv. jariq

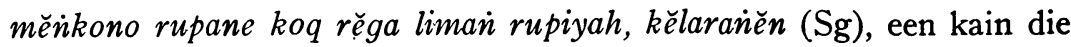
er zo uitziet( als daar bij jou of zoals daar ligt), en die notabene vijf gulden kost, dat is te duur. Hier zou mĕńkana, voor mĕńkono gesub- 
stitueerd, betekend hebben: die kain die daar ginds zich bevindt, of die kain waarover we het toen, bij die gelegenheid hebben gehad.

$\mathrm{Er}$ is echter nog een derde onderscheiding in de betekenis van mènkono en riono aan te wijzen, een onderscheiding die geheel dezelfde is als bij $i k u$; měnkkono kan ook generiek gebruikt worden : bañsa luhur měnkono, najan mlarat isih diajeni won் $(\mathrm{Sg})$, mensen van adel worden, ook al zijn ze arm, toch nog geëerd; bocah nono pintĕra dikaya n்apa, měsți kalah akal karo won tuwa (Sg), kinderen ook al zijn ze nog zo knap, leggen het toch in verstand tegen ouderen af.

$Z$ ich aansluitend bij deze generieke waarde komt měnkkono ook voor ongeveer in de betekenis van: zó, d.w.z. op zichzelf genomen, alleen, slechts, wat betreft. Vaak verleent het aan het voorafgaande woord slechts een zeker reliëf. Gevallen van gebruik: rupane měrikono ora bagus, nanin pintěre tanpa tandin (Sg), zijn uiterlijk - dat alleen genomen - is niet knap, maar zijn intelligentie is niet te evenaren; dĕdĕge měnkono endeq, jĕbul rosa (Sg), van gestàlte is hij klein, maar hij blijkt toch sterk te zijn; pañcene mainkono iya kĕsĕl bainĕt, naìin kĕpriye měneh, sandañanku durun pada garin (PPT I 57, 23), ja eigenlijk (d.w.z. alleen op de feiten gelet) ben ik erg moe, maar wat wil je er aan doen, mijn kleren zijn nog niet droog.

Verder komt vooral nono en bij afkorting no in het bijzonder aan het eind van de zin frequent voor met een soort affectieve betekenis die in het Nederlands ongeveer weer te geven is met: hoe vind je zo iets, stel je voor, waarachtig. Gevallen van gebruik: o, bocah kuzer! ana ragaian rana diango tunganian n்ono! (LBK 48, 10-9 v.o.), die kinderen toch! een houten raam van een schutsel wordt waarachtig gebruikt om op te rijden! (zegt moeder boos tegen de kinderen als ze treintje spelen met het houten geraamte van een schutsel); muduna, raq iya rusaq no ménko (LBK 48, 9-8 v.o.), ga er af, dadelijk gaat hij immers kapot (zegt de moeder vervolgens); $M a$, kowe ora rosa nono (LBK 77, 30-31), (Dar)ma, je bent niet stèrk; yah ene ki ana íanten no (BG II 42, 22), op zo'n uur als dit nog een bruiloft!

Worden deze twee laatste betekenisonderscheidingen van mĕikono of nono geactueerd dan kunnen zij zonder aanwijsbaar betekenisonderscheid vervangen worden door mono. Zo is mogelijk: gajah mono gĕde lan rosaa kae, kĕna direh manuisa ( $\mathrm{Sg}$ ), aan olifanten hoe groot en sterk ze ook zijn, kan de mens zijn wil opleggen; mula pasa mono yen ditěměnani kaṇti ati sin rĕsiq bisa n்edap-edapi pikolehe (OOA 83, 12-14), daarom, wanneer men het vasten ernstig (en) met een rein gemoed opvat, dan kan het nut ervan verbazingwekkend zijn; anane 
pranatan gawe omah... karěpe mono iya apiq bainĕt (BD 166, 3-1 v.o.) dat er een verordening is voor het bouwen van huizen... de bedoèling er van is heel mooi; aku mono sagletaq-gletaqe (PPT I, 57, 28), wat mij betreft, ik (slaap wel) waar ik maar kom te liggen. In spreektaal is dit mono uiterst frequent; veelvuldig treft men het aan na woorden als sañatane, pañcene, sajaqe. Op grond van de substitutiemogelijkheid van mono voor měńkono en gezien het feit dat mono in deze gevallen nooit te vervangen is door sěmono, en in aanmerking genomen de in gebruik zijnde procédé's van inkorting lijkt het voor de hand te liggen om dit mono als een verkorting van mérkono te beschouwen.

Aandacht verdient voorts de combinatie ora ínono (kr. botěn íatěn) die in conversatie veel wordt gebruikt, wanneer men op een ander onderwerp overgaat, bijv. ora niono, kan், kowe neq turu apa iya kĕpenaq (OOA 13, 9-8 v.o.), maar nu heel wat anders, slaap je goed? Onzeker is het of men in dergelijke gevallen wel ora měnikono gebruikt.

Tenslotte mënkana en inana. Deze worden in de eerste plaats gebruikt in de betekenis van zoals daar ginds, zoals toen indertijd, zo groot als daar ginds. Gevallen van gebruik : wayah mĕnkana kuwi si Karya durun tani, raq aneh, sabab adate jam ném zois ana saz'ah (Sg), is Karja zólaat nog niet op, wat vreemd, gewoonlijk is hij immers om 6 uur al op de sawah; apa gunun ki (= kuwr) yen dicĕdaqi iya alus kaya inana kae (OOA 5, 4-5), zijn bergen als je er dichtbij komt werkelijk zó glad (zoals men daar in de verte ziet) ?; bocah kaya mĕnkana rupane koq inaku bagus (Sg), de jongen die er zo uit zag als we toen bij die gelegenheid zagen, beweert notabene dat hij knap is!

Daarnaast komen měnkana en inana voor met een betekenis die vergelijkbaar is met kae, die bekende, zoals je weet. Men zou dan mĕnkana en inana kunnen weergeven met: zoals dat kan gebeuren, zoals dat zou kunnen zijn, zoals men zou kunnen denken. Wordt van měnikana of inana deze betekenisonderscheiding geactueerd, dan zijn deze woorden door mana te substitueren. Dit mana is in spreektaal zeer frequent, frequenter naar het lijkt dan měnkana en n்ana. Het gebruik is gebonden aan zinnen waarin een veronderstelling wordt gemaakt, d.w.z. in zinnen met upama of eingane of wel aan een verbale irrealiteitsvorm. Gevallen van gebruik: upama lalakone paq de ditulisa mana, bisa dadi buku géde (TjB I 36, 2-1 v.o.), gesteld dat men alles wat oom meegemaakt had zou opschrijven, zoals men dat zou kunnen doen (zoals anderen dat wel doen), dan zou er een groot boek ontstaan; tujune ora ana putri lizeat, éngane ana mana geq krun்u i்ĕndikane kañmas mau, baya 
angone maleroq íanti tělun dina (SR 14/15), gelukkig liepen er geen jonge dames voorbij, als dat wel zo geweest was, wat heel goed zou hebben gekund, dan zouden ze indien ze uw woorden gehoord hadden, wel drie dagen lang met schuine blikken van afkeer gekeken hebben; $\dot{n} e$ ndi ana těka-těka bañjur něsu, cocode urab-uraban, polahe briga-brigi kaya bansat, kaya diwědenana mana (BD 37,6-7), hoe is het mogelijk dat je nauwelijks gekomen, meteen maar kwaad wordt, maar gemeen begint te schelden, een dreigende houding aanneemt als een boef, alsof men bang voor je zou zijn, (zoals je denkt dat wel zou kunnen gebeuren). Evenals in het geval van mono nemen wij op dezelfde gronden aan dat mana een afkorting is van měnkana.

Volledigheidshalve vermelden wij nog dat in lakon-teksten markana voorkomt als deftige vorm in plaats van mĕrkene, bijv. in de lakon Kurupati rabi ed. te Mechelen p. 203 : mainkana painudasmaranin driya sri bupati in Madura, zo (als thans volgt) was hetgeen in het hart van de vorst van Madura omging.

Slechts pronomina van de eerste en van de tweede horizontale rij kunnen worden gecombineerd: mĕrikene-mĕnikono / nene-ñono is de enige welke schijnt voor te komen met de betekenis zus en zo, allerlei bijv. ditakoni měnkene-mĕnkono, měnĕ $\dot{n}$ bae, sasat kaya won bisu (Sg), hoewel men zus vroeg en zo vroeg, hij zweeg maar, als was hij een stomme. Gevallen in teksten zijn wij tot dusverre niet tegengekomen.

De morfologische procédé's die bij deze pronomina mogelijk zijn zijn de volgende: 1 . suffigering van $-a, 2$. suffigering met $-n e, 3$. verdubbeling, 4. verdubbeling met zgn. vocaalvariatie, 5. suffigering van -ake, 6. suffigering met $-i$.

Ad 1: De vormen met - $a$ vindt men in wensende of veronderstellende of concessieve zinnen: muga-muga sabañjure tansah měnkonoa ( $\mathrm{TjB}$ I, 87, 8-9), moge het in het vervolg steeds zo zijn; nonoa kuwi, boq sesuq wae, ta, le, bali (RS 56,11), ook al is dat zo (nl. dat je morgen op school in Lawang moet zijn), keer toch morgen maar terug, jongen; těna nika botěn kĕmbar kalih kamas (KA 11, 7), ook al is dat zo, deze (kain) past niet bij (die van) mijn broer. Vaste combinaties waarin deze -a-vormen voorkomen, zijn 1) met achtergevoegd kae: měrikonoa kae, koq iya měksa kuran் marěm, neq ora diunduh dewe (AMK 63, 2-3), ook al is dat zo, toch is hij werkelijk niet voldoende gerust, als hij ze niet zelf oogst, 2) met voorgevoegd soq: soq měrikonoa si Sumardi iku kěna inaran kagĕden ěndas kuran் utěk (MMTj II, $5 / 6$ ), als het zo is (als ik het goed begrijp) dan mag men zeggen dat die Sumardi een te groot hoofd heeft en te weinig hersenen. 
Ad 2: Het geringe materiaal wettigt de conclusie dat deze formatie wel mogelijk is, maar zelden voorkomt. Er is geen eenvormigheid in de van informanten verkregen gegevens. Volgens Slamet Roosman, onze uit Semarang afkomstige informant, komt een vorm als inenene wel voor, welke nadrukkelijker is dan de suffixloze vorm, bijv. gambar kaya inenene ki karĕpe piye ta (SlR), zeg, zón tekening wat is de bedoeling daar wel van. Uit het materiaal van mijn informant-assistent Soegiarto, afkomstig uit Solo, blijkt dat door suffigering transpositie naar de substantiva plaats vindt: Karya sabane saiki in bambon, nonone $i k u$ sěbab ñakot olehe madat $(\mathrm{Sg})$, Karja gaat nu vaak naar de opiumkit, dat dit zo is komt doordat hij aan het schuiven verslaafd is geraakt.

Ad 3: Gevallen van verdubbeling blijken zeldzaam te zijn; het enige geval waarover we beschikken is de zin pañcen laran, nin raq dudu baran sin n்ono-ñono kuwi (BG II 61, 9-10), inderdaad, kostbaar, ja maar natuurlijk niet zulk soort dingen (zoals jij daar laat zien). De verdubbeling lijkt hier diversiteitsbetekenis te hebben, maar dit ene geval is uiteraard niet voldoende voor het trekken van een conclusie in deze. Syntactische verdubbeling in contrastzinnen komt wel regelmatig voor: notěn-n்otěn niku, raq margi sakin lëpate piyambaq (BD 78, 9 v.o.), dat dat zo is, komt omdat het immers zijn eigen fout is (RS 47, 10: nin n்ono-ñono kuwr saka salahe dewe).

Ad 4: In teksten troffen wij slechts aan vormen die op $\dot{n} e n e$ zijn gebouwd, in de meeste gevallen in combinatie met het procédé van suffigering van -a, bijv. ah wis ben, bune, baran sin wis kĕbacut kurri aja korěmbug lan ora prělu kogětuni, arěpa niena-ñene kae woǹ wis diniyati, kowe aja kĕdureun (OA 74, 18-20), ach laat maar, moeder, wat nu eenmaal al gebeurd is, praat daar maar niet over en daar moet je maar niet over treuren, hoe het (verder) ook zal gaan, wij hebben het nu voorgenomen, heb maar geen spijt; inena-ñenea, ya luputku derve (SW 55, 13 v.o.), ook al is het zus of zo, het is toch mijn eigen fout.

Ad 5: Door suffigering met -ake worden afleidingen met indirectrelationele betekenis gevormd. De verdubbeling die hierbij optreedt heeft intensiteitsbetekenis. Ook combinatie met verdubbeling met vocaalvariatie is mogelijk. Gevallen van gebruik: mas ajĕn, mĕnazer kula dipunměkatěnakěn ingih alurenin kondur kemawon datěn Nayoja (AW 45, 6-5 v.o.), mevrouw, indien men mij zo bejegende, dan keerde ik liever terug naar N.; pěñjaluqku: dadia arĕp diměnkenaq-měnkeneqake, boq iya gělis, dadi aran ora ndědawa wiran் (MMTj II, 10, $24-25$ ), wat ik verlang is, ook al komt het er van dat men zus of zo 
met mij handelt, laat het snel geschieden, kortom laat men niet mijn schande verlengen.

Ad 6: Hoewel de gegevens nog onvoldoende zijn, lijkt het toch zeker, dat verba met $-i$ op basis althans van měnkene mogelijk zijn, bijv. wo iki ñata alim lan sabar, dimaìkeneni ora něsu $(\mathrm{Sg})$, deze man is kennelijk een wijs en geduldig man, zó behandeld, wordt hij toch niet boos. Het betekenisverschil tussen de $-i$ vorm en de $-a k e$ vorm is geheel gelijk aan die welke normaal tussen beide verbale categorieën bestaat. ${ }^{30}$

Ten aanzien van de syntactische valentie nog enkele opmerkingen. Evenals $i k i$ enz. kunnen měnkene enz. zowel deel uitmaken van onderwerp-gezegde groepen van verschillende typen als van substantief groepen. In deze laatste komen zij na $i k i$ : wayah mĕńkene $i k i$, op dit zodanige tijdstip; hoewel in dit soort groepen veelvuldig pronomina van dezelfde horizontale rij voorkomen (mĕnkene $+i k i$, měnkono + $i k u)$ is toch het voorkomen in één groep van mërkene en kae niet uitgesloten, wanneer nl. kae betekent die bekende, weet je wel. Zo bijv. iki raq pada bae karo won maido mańkene kae... (OP 23, 1-2), dit is immers net zo als wanneer iemand het volgende (dat je wel kent) betwijfelt (nl. dat een man getrouwd met een knappe vrouw, toch een sělir er op na houdt).

\section{De mrene-serie}

Tot deze serie behoren de volgende pronomina:

\begin{tabular}{|ll|l|}
\hline \multicolumn{2}{|c|}{ ngoko } & krama \\
\hline mrene & rene & mriki \\
mrono & rono & mriku \\
mrana & rana & mrika \\
\hline
\end{tabular}

Speciale madya-vormen doen zich niet voor. De serie rene, rono, rana met reductie van de initiële consonantcluster - een reductie, die wij ook elders antreffen $\mathbf{3 1}$ - komt in de spreektaal voor en in teksten die gesprekken weergeven. De verschillen in betekenis tussen de vormen van de drie horizontale rijen lopen geheel parallel met die tussen de rijen neutrale en locale demonstrativa die wij hierboven

30 Verb structure in Javanese, For Roman Jakobson 1956, p. 567 sq.

31 De structuur, p. 234. 
bespraken; mrene, hierheen, wijst in de richting van de spreker van de zin, waarin mrene voorkomt; mrono, daarheen, in die van de hoorder of althans naar iets binnen de spreeksituatie; mrana, gindsheen, in de richting van iets of iemand buiten de spreeksituatie. Ter illustratie enige gevallen van gebruik: olehku pada boyon mrene, ora niyat goleq sěněn, nañin goleq luwih lëmah (AMK 33, 18-20) dat wij hierheen emigreren doen we niet voor ons plezier, maar omdat wij op zoek zijn naar meer grond; Pon wis wěruh karo woǹ wadon mau, sabab gawene mrono, adol kayu (PPB 6/7), Pon kende die vrouw al, omdat het haar werk was om (geregeld) daarheen te komen, om hout te verkopen; apa bapaqmu aweh kowe mrana? (AMK 11, 4), mag je van je vader daar ginds heen gaan?

De volgende onderlinge combinaties komen voor: 1) mrene-mrono, 2) mrana-mrene, waarnaast ook de gereduceerde vormen rene-rono en rana-rene en de corresponderende krama-vormen voorkomen. Gevallen van gebruik: dureitku mun sĕmene kĕna dingo lĕlunan mrene-mrono, ora cukup yen arěp mrana ñan tanah sabraì (Sg), ik heb maar zo veel geld, genoeg om hier of daar eens een tochtje naar toe te maken, maar het is niet genoeg als ik ginds naar de overwal wil; mrika-mriki kĕmirěnan szearanipun tiyan் damĕl griya utawi gubugan (PPT I 16, 21-22), ginds en hier, d.i. overal was het geluid te horen van mensen die huizen en optrekjes maakten. Het onderscheid in betekenis tussen beide typen composita is identiek aan het verschil tussen de combinaties besproken bij de vorige serie.

Thans de morfologische valentie. Mogelijk zijn de volgende procédé's : 1 . suffigering van $-a, 2$. suffigering van $-n e, 3$. verdubbeling, alleen bij mrana, 4. verdubbeling met vocaalvariatie, 5. suffigering met -ake (krama -akĕn). Gevallen van gebruik:

Ad 1: In deze serie hebben de vormen met suffix $-a$ overwegend imperatieve betekenis: sesuq bae kowe mranaa, urusĕn ṅanti oleh kať̌ranan sin cĕț (MMTj I 51, 2-1 v.o.), ga morgen maar daarheen, en onderzoek de zaak totdat je volkomen opheldering hebt gekregen. Bijzonder frequent is de imperatief $(m)$ renea, kom hier en, wanneer men iemand roept die zich op grote afstand bevindt, met geinfigeerde -o- die verlenging ondergaat en een hoge toon draagt; mrenóe, kom eens hiér!

Ad 2: Door suffigering met -ne treedt transpositie op naar de sub-

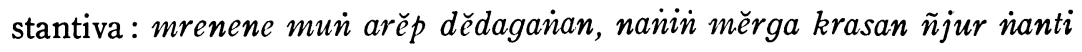
taunan ana kene $(\mathrm{Sg})$, hij kwam hierheen (zijn hierheen gaan was) 
alleen om handel te drijven, maar omdat hij (er) zich thuis voelde, bleef hij jarenlang hier. Ook suffigering van $-k u$ en $-m u$ is mogelijk: mronomu kudu ingawa karcis, yen ora, mĕsți dibaleqake sin jaga lazean $(\mathrm{Sg})$, als je daarheen gaat (je daarheen gaan) moet je een kaartje hebben, heb je dat niet, dan word je zeker teruggestuurd door de portier; mrenene měñà ìĕndi? (SIR), als men deze richting ingaat, waar gaat men dan heen?; umuripun tiyan் punika ... ñènkanipun satus taun; sapunika mas wĕdana sampun umur sawidaq taun, lah raq sampun katah mrikanipun (SS 150,3-7), de leeftijd van de mens ... op zijn hoogst wordt hij honderd jaar; nu is de wedana al 60 , hij is dus al aardig in de (gindse) richting.

Ad 3 : saka bĕbĕgin atine paq modin mari ṅantuq, gagasane ìlambrain mrana-mrana (BD 133, 20-21), doordat zijn gemoed vol was met gedachten kon de modin niet meer slapen, zijn gedachten zwierven ver overal heen; ... la apa pilih dur'e bojo sìn sěněn main domino, apa bal-balan, apa plěsir rana-rana? (ER 58, 1, 31-33), of wil je liever een man hebben die houdt van dominospelen, of van voetballen, of overal maar heen uitgaan? Naast deze morfologische verdubbeling komt bij deze serie ook syntactische verdubbeling voor van bekende, reeds elders besproken typen. ${ }^{32} \mathrm{Wij}$ volstaan daarom met het geven van een zin van beide typen: z'on kuwi ora tau tuku baran in tokoku; mrene-mrene, barěn aku duze dagainan sin toko liya pada ora duwe $(\mathrm{Sg})$, die man kocht nooit in mijn winkel, hij kwam hier alleen heen, toen ik koopwaar had, die de andere winkels niet hadden; apa ana gawemu? Botěn, mïn tuwi mawon; ěmpun lami botěn mriki-mriki (OOA 47, 1-2), kom je met een bepaald doel? Nee, ik kom alleen maar op bezoek, al lang ben ik niet hierheen gekomen.

Ad 4: Verdubbeling met vocaalvariatie: čngone mrona-mrono kuwi sěbab kĕpenin dipeq mantu oleh anaqe wadon sudagar mau (Sg), dat hij telkens maar daarheen gaat (gezegd met een zekere ergernis) is omdat hij verlangt tot schoonzoon genomen te worden en de dochter van die koopman te krijgen; zreh, cah, aku saběn dina tampa layan, ditagihi rena-rene, jarene ěndi olehe arĕp mariüi běbuinah (TB 8, 2, $1-3)$, ach, jongens, ik ontvang iedere dag brieven, steeds maar richt men tot mij hier aanmaningen, (mij vragend) wanneer toch de geschenken zullen worden gegeven.

Transpositie naar de verba komt in deze serie regelmatig voor door suffigering van -ake, krama -akěn: dimreneqake, dipunmrikeqakĕn enz.,

32 Zie BKI 109 (1953) en 110 (1954). 
hierheen verplaatsen. Ook taq-en $k o q$-vormen en alle andere verbale vormen die regelmatig naast de -ake-vormen voorkomen, doen zich ook hier voor. Een geval van gebruik: si Marna dimreneqake supaya oleh hazea liya sin sĕgĕr, ben engal mari larane (Sg), Marna is hierheen gebracht, opdat hij andere, frisse lucht krijgt om spoedig te genezen van zijn ziekte.

De syntactische valentie van de directieve pronomina is anders dan die van de kene-serie. Met substantieven kunnen zij niet direct verbonden worden, wel via sin (bocah sin mrana wis akeh, de kinderen die daarheen gaan zijn al veel (in aantal). Maar zij kunnen wel verbonden worden met verschillende typen verba en verbale groepen bijv.: $a k u$ arĕp mrono, ik wil daarheen; goleq utanan mrana ora oleh, ginds iets trachten te lenen, had geen succes; apa bapaqmu aweh kowe mrana (AMK 11, 4), vindt je vader goed dat je daarheen gaat? Wij moeten ons hier tot deze enkele opmerkingen bepalen.

\section{De sĕmene-serie}

Deze serie omvat de volgende vormen:

\begin{tabular}{|c|c|c|}
\hline Ngoko & Krama & Madya \\
\hline $\begin{array}{c}\text { sĕmene }- \text { mene } \\
\text { sěmono - mono } \\
\text { sěmana }- \text { mana }\end{array}$ & $\{$ sĕmantěn & $\begin{array}{l}\text { sĕmentěn } \\
\text { sěmontěn } \\
\text { sěmantěn }\end{array}$ \\
\hline
\end{tabular}

Van de krama-vormen is sěmantěn alleen in de standaardtaal gebruikelijk. Evenals mĕnika en měkatěn treedt het daar als ceremoniële term op naast alle drie de ngoko-termen. Sëmentěn en sĕmontĕn zijn behalve madya, ook dialectische krama-vormen.

De verkorte vormen komen in vlotte spreektaal frequent voor: těk $a$

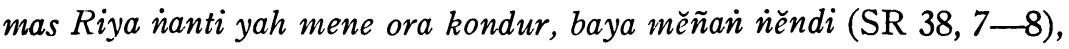
wat vreemd dat mas Rija(nta) zo laat nog niet thuis gekomen is, waar zou hij toch heen zijn? Vaak wordt juist in combinatie met yah (= wayah) dit mene verder verkort tot ene: ana yah ene koq jogedan (BG II, 25, 6), zo vroeg nog en dan al aan het dansen!; yah ene kĕnduren kuzeri wis mokal (BG II, 39, 22), nu het al zo laat is, een slametan, dat is uitgesloten. Dit ene < mene moet niet verward worden met ene als verdere verkorting van inene; in de zin ana yah ene koq 
jogedan kan ene ook opgevat worden als inene. De zin betekent dan op zo'n (ongewoon) tijdstip en dan aan het dansen. In teksten is in sommige gevallen, als de situatie geen steun geeft, moeilijk uit te maken welk ene er gebruikt is.

Karakteristiek voor deze serie is dat zij naar betekenis en naar morfologische en syntactische valentie aan de ene kant deel uitmaakt van de systematiek van de pronomina demonstrativa en ruimer van het geheel der Javaanse pronomina, aan de andere kant mede behoort tot de numeralia. $\mathrm{Zij}$ kunnen dus in de Javaanse morfologie of als onderdeel van de pronomina of als deel der numeralia of als een afzonderlijke categorie behandeld worden; hier zullen we vooral ingaan op het pronominale aspect, aangezien wij in onze beschrijving van de numeralia reeds aan het numerale aspect de nodige aandacht hebben geschonken. ${ }^{33}$

De verschillen in betekenis tussen de drie horizontale rijen zijn weer in het algemeen gesproken dezelfde als die tussen de tot dusver behandelde pronomina. In de betekeniseenheid van sěmene zijn twee frequent toegepaste onderscheidingen aanwezig. In de eerste plaats sěmene, quantitatief (zoveel, zo weinig) als hier bij mij (de spreker), bijv. nora ñana nora nimpi, yen aku nè tanah sabran் nĕmu kabĕgjan samene (AMK 11, 7-5 v.o.), ik had nooit kunnen dromen, dat ik in het kolonisatieland zóveel voorspoed zou ondervinden (als ik thans ondervind). In de tweede plaats komt sěmene voor aan het eind van een gesprek, verhaal of brief en betekent dan: zoveel of zover als de spreker en de hoorder nu gekomen zijn, bijv. wis, wis samene bae disiq bab iki (BD $172,13)$, genoeg, genoeg, laten we voorlopig maar hier blijven met dit onderwerp; kaya wis cukup samene bae (TjB I, 109, 4 v.o.), het lijkt voldoende om hier (waar we nu zijn) maar te blijven. Sĕmene contrasteert dan met sěmono op dezelfde wijze als $i k i$ tegenover $i k u$ en vooral duidelijk als měnkene tegenover měnkono; sěmono wijst namelijk juist terug naar het reeds eerder gesprokene, bijv. samono kaměmpěnane won̈-won in kene ěngone arĕp mbiyantu inențenake sasangane Nagara (K, 1261, 2, 12-14), zo groot, (nl. als door het voorafgaande is duidelijk gemaakt) is de vastbeslotenheid van de mensen hier om de lasten van de regering te helpen verlichten; yen wis těkan samono jamane, wis, Truq, aku narima dadi... lengger alias tledeq lanain bae (BD 175, 1-2), als zulke tijden aangebroken zijn, dan, Troek, berust ik er in om maar een lengger (als danseres verklede of gemaskerde

33 BKI 109 (1953). 
man) of te wel een mannelijke tledeq te worden. Vaak vindt men dit terugwijzende sěmono in verbinding met uga, mau en $i k u$ : samono uga bab carane adol wade karo luriq kuwi (K 400, 2, 7-5 v.o.), en zo ook (nl. als reeds eerder is uiteengezet) wat betreft de methode van het verkopen van gebatikt en gestreept goed. Sĕmono uga kan in zulke gevallen zonder voor mij vaststelbaar betekenisverschil vervangen worden door mě̀nkono uga.

Gevallen van gebruik met mau en $i k u$ : baran-barain kaingo gawe omah won்-woì man manawa bisa oleh slaka painreh praja ... rĕgane kabayar tèmbe buri. Samono man manawa woñ-won man pañcen ora bisa oleh baran-barain mau ... (BS 111, 8-11), materiaal om een huis te bouwen, wanneer die mensen dat kunnen krijgen van het bestuur..., dan kan het bedrag later betaald worden. Zulks is het geval als de mensen zich werkelijk niet die materialen kunnen verwerven...; pañcen, samono kuwir, neq kapintěrane ora ditañjaqake ( $\mathrm{K} 527,2,16-17$ ), inderdaad, zulks is het geval wanneer zij zich hun kennis niet ten nutte maken.

Sĕmono wordt behalve in bovengenoemd geval ook gebruikt in de betekenis van: op dat ogenblik d.w.z. niet een ver in het verleden liggend tijdstip waarop de spreker terugkijkt, maar een al of niet in het verleden liggend tijdstip dat de spreker in de gegeven zin present stelt, actualiseert. Hoewel combinatie met woorden als dẹ, kala, nalika, wěktu uiterst frequent is, is echter hun aanwezigheid voor de activering van deze temporele betekenis van sěmono niet beslist nodig. Zo bijv. sarta wizert samono aku bañjur dipracaya uzvon (MMTj II 50, 6-5 v.o.), vanaf dat ogenblik vertrouwden de mensen mij.

Hiertegenover wijst sěmana altijd op een buiten de spreeksituatie van het ogenblik liggend feit, indien het temporeel gebruikt wordt; daarnaast betekent sěmana natuurlijk ook: zoveel of zo weinig als daarginds. Gevallen van gebruik: nalika samana larwasiñ pasinaon mun tĕlun taun ( $\mathrm{TjB}$ I, 122, 9-10), toentertijd duurde de opleiding slechts drie jaar.

Behalve de numerale procédé's die op deze serie kunnen worden toegepast (ñĕmene, ron் mene etc. sěmene-sěmene), waarvoor wij naar de beschrijving van de numeralia verwijzen, dienen de volgende hier genoemd te worden: 1 . suffigering van $-a, 2$. suffigering van $-n e, 3$. verdubbeling, 4. suffigering van -ake. T.a.v. de twee eerste kunnen we volstaan met een enkele zin, aangezien deze $-a$ en $-n e$ vormen analoog zijn aan de $-a$ en $-n e$ vormen die bij de andere series besproken zijn.

Ad 1: sěmenea kae měksa kĕlarainĕn (Sg), ook al is het zoveel, toch is het te duur.

Ad 2: sĕmenene iki rĕgane pira (SIR), zoveel (als ik hier aanwijs) 
ervan (bijv. een bepaald segment van een koek) hoeveel kost dat?

Ad 3 : Het door mij vroeger besproken geval van verdubbeling sěmentěn-mentěn met intensiteitswaarde 34 blijkt toch niet zo zeldzaam te zijn als ik indertijd dacht. Elders vond ik precies met dezelfde waarde: wah, neq mlayu, kana ñjaikah sapisan, padane aku pin sĕpuluh; won sikile samana-mana (PPB 30/31), verbazend, als we hard lopen, dan neemt hij één stap tegenover ik tien, want hij heeft immers zúlke grote poten! (een hond is hier aan het woord). Hoewel het materiaal nog te gering is om meer dan een voorlopige conclusie te trekken, is mijn indruk nu toch dat bij de serie van sěmene twee verschillende procédé's van verdubbeling mogelijk zijn, één van volledige verdubbeling sĕmene-sěmene, dat zich aansluit bij wat bij de numeralia mogelijk is en een procédé van gedeeltelijke verdubbeling (sěmana-mana) dat overeenkomt met wat we bij de pronomina vinden. Nader onderzoek zal moeten uitmaken of deze zienswijze juist is.

Of verdubbeling met vocaalvariatie mogelijk is, hebben we niet met zekerheid kunnen bepalen. Gevallen van gebruik in teksten zijn overigens begrijpelijk - niet gevonden. Toch acht ik gezien de productiviteit van dit procédé in de gesproken taal de mogelijkheid van deze vormen ook hier geenszins uitgesloten. Ook gegevens over mogelijkheden van combinatie staan mij niet ter beschikking.

Ad 4: Vormen als disěmeneqake, gemaakt dat het deze hoeveelheid wordt, zijn te vormen, al zullen zij niet frequent zijn. In teksten hebben wij deze vorm tot nu toe niet aangetroffen.

Over de syntactische valentie tenslotte slechts enkele opmerkingen. Als $i k i$ en kene kan sĕmene c.s. staan in bepaalde onderwerp-gezegde groepen (sěmene wis cukup, zoveel is al voldoende) en ook in substantiefgroepen (duwit sěmene iki arĕp dingo sainu, deze hoeveelheid geld zal ik voor op reis gebruiken).

\section{De sĕprene-serie}

Het is nauwelijks geoorloofd om hier van een serie te spreken. Slechts van de vormen van de eerste en derde horizontale rij is het zeker dat zij in de standaardtaal voorkomen; de vorm sĕprono welke wel in het woordenboek van Pigeaud wordt vermeld, kenden mijn informanten niet, terwijl ik ook in teksten tot nu toe deze vorm niet tegengekomen ben. Een theoretisch denkbaar daarmede corresponderende krama-vorm sěpriku is ook bij Pigeaud niet te vinden.

34 BKI 109 (1953), p. 373. 
Daar verkorting zich niet voordoet en er ook geen speciale madyavormen voorkomen, zijn de te bespreken vormen slechts :

\begin{tabular}{|c|c|}
\hline Ngoko & Krama \\
\hline sěprene & sěpriki \\
- & - \\
sěprana & sěprika \\
\hline
\end{tabular}

De betekenis van sěprene is : tot op dit moment nl. tot op het moment waarin de zin gesproken wordt waarin het woord sěprene voorkomt bijv. zerivit biyen nanti saprene para nonoman pada karĕm maraì ulah raga $(\mathrm{T} \mathrm{jB} \mathrm{I}, 154,12-14)$, van vroeger af tot op dit moment is de jeugd erg gesteld op sport. Hiertegenover betekent sěprana tot op dat moment, tot zo lang, wijzend op een tijdstip dat buiten de spreeksituatie ligt: kandane Suma sawise sěprana ìgone ìěnteni kañcane mĕksa ora těka, ñjur ditingal luña (Sg), Suma zei dat hij nadat hij tot zo lang op zijn makkers had gewacht en zij toch niet gekomen waren, toen maar niet langer op hen gewacht had.

De enige combinatie welke voorkomt is sěprana-sěprene (krama sěprika-sěpriki), van die tijd af, tot op dit moment, een formatie die ook qua betekenis analoog is aan mrana-mrene en kana-kene. Gevallen van gebruik: wizerit nalika patine anaqe sin mbarěp paq Jaya sěpranasĕprene duruin lipur (Sg), van het overlijden van zijn oudste zoon af tot op heden is Djaja nog steeds niet over zijn verdriet heen. Een vaste combinatie is: sěprana-sěprene ora, tot op dit moment nog steeds niet.

Er bestaan geen morfologische procédé's die op deze pronomina toegepast kunnen worden. Syntactische procédé's (suffigering van $-a$ en verdubbeling) zijn wel mogelijk. De enige vorm waarvan het bestaan verder vaststaat, is de verdubbeling sěprene-prene. Wij vonden deze vorm tot nu toe slechts één keer in een tekst: keyoì dikon mlěbu nomahe; lah sěprene-prene mrana-mrana omahe digendon் wae (LBK $71,6-5$ v.o.), de slak moest (van de leeuw) zijn huis binnengaan; nou en van dàt moment af tot nu toe draagt hij zijn huis maar steeds (overal heen) op zijn rug (uit een dongeng die verklaart waarom de slak zijn huis altijd op zijn rug draagt). Hier had ook sěprene kunnen staan; het betekenisverschil door de verdubbeling teweeggebracht, is verhoogde nadrukkelijkheid, grotere intensiteit. Men vraagt zich af of deze vorm 
niet volkomen parallel is met de hierboven genoemde pronomina sěmentěn-mentěn en sěmana-mana.

Wat de syntactische valentie aangaat van sĕprene en sĕprana het volgende. Sëprene (niet sěprana) kan verbonden worden met kiye en $i k i$, bijv. wizert in dina mau saběn sore aku ndĕdĕp ana kene, iya ṅanti tuměka sěprene kiye (PPT I 54, 23-24), vanaf die dag lag ik hier elke avond op de loer, tot nù toe. Hier zou ook alleen sĕprene hebben kunnen staan; kiye legt hier een sterke nadruk. Gevallen van verbinding van sĕprana met kae heb ik niet gevonden. Ondenkbaar is het niet dat zij toch voorkomen. Voorts komen beide voor in direct verband met onderwerp-gezegde groepen: saprene sirahe isih koplaq (SK 95, 20), tot nu toe bonst zijn hoofd nog; sapriki kiran laìkun sampun wontĕn kawan taun (OA 17, 25), (tot) nu (toe) al ongeveer vier jaar geleden.

In de derde plaats kunnen zij ook deel uitmaken van een onderwerpgezegde groep : sĕprana ṅgone ìěnteni kañcane (Sg), tot zo lang wachtte hij op zijn vrienden. Direct verbonden kunnen zij ook worden met een voorafgaand ianti of een voorafgaand samengesteld telwoord: tandane nanti saprene pañjĕněnan durun parin kabar maneh ( $\mathrm{Dj} \mathrm{P} 46,17-18)$, het bewijs er van is dat $\mathrm{u}$ tot op dit moment nog niets van $\mathrm{u}$ hebt laten horen; limain taun saprene isih duzve sawah dewe (ER 60, 1, 24-26), vijf jaar geleden had hij nog zijn eigen sawah.

\section{Samenvatting}

$\mathrm{Na}$ deze gedetailleerde behandeling volgt hierachter thans een samenvattend overzicht van al de pronomina demonstrativa en de procédé's, die op hen toegepast kunnen worden. Een lege plaats duidt aan dat een bepaalde vorm niet voorkomt, het tussen haakjes plaatsen van een woord, dat hoewel geen gevallen van gebruik tot nu toe zijn gevonden, wellicht toch de mogelijkheid bestaat dat het wordt gevormd. Niet alles is in dit overzicht opgenomen. Krama-, madya-vormen en afkortingen zijn, terwille van de overzichtelijkheid, niet vermeld.

Duidelijk blijkt de eigen structuur van deze pronomina. De morfologische valentie is over het geheel genomen gelijk; opvallend is ook dat de frequent voorkomende -an/-n-suffigering die bij de substantiva, de verba, de adjectiva en de numeralia zulk een belangrijke rol speelt, hier nooit optreedt. Zelfs in de transpositieverschijnselen is een zekere overeenkomst waarneembaar, al neemt ook de sěmene-serie door zijn hybridisch karakter een bijzondere positie in.

Verh. dl. XXX 


\section{PRONOMINA INTERROGATIVA ET INDEFINITA}

\section{De categorieën}

De pronomina interrogativa et indefinita vormen een groep met een eenvoudige structuur. Bij de serie sapa, apa, ěndi, kĕpriye, pira en kapan zijn de volgende procédé's mogelijk: 1 . suffigering van $-a, 2$. verdubbeling, 3 . verdubbeling met tussenvoeging van $t a$, 4 . verdubbeling met vocaalvariatie, 5 verdubbeling met suffigering van $-a$. Incidenteel komt voorts nog suffigering van $-n e$ voor. Ook in deze groep corresponderen regelmatig krama-vormen met de ngoko-pronomina; alleen bij kapan is deze oppositie niet aanwezig. Daar er slechts enkele vormen niet schijnen voor te komen en slechts bij enkele zich nog enige andere vormingsmogelijkheden voordoen, is de bouw van deze gehele groep bijzonder regelmatig, zoals uit het hiernaast afgedrukte tableau blijkt.

De pronomina van de eerste kolom wijzen resp. naar een persoon, zaak, plaats, wijze, hoeveelheid of tijdstip, waaromtrent de spreker geen nadere specificatie geeft of wel deze specificatie van de hoorder verlangt te ontvangen. Afgezien van nog andere gebruiksmogelijkheden van $a p a$ en $\breve{n d i}$, die hieronder nog in een afzonderlijke paragraaf aan de orde zullen komen, kan men dus vaststellen dat deze pronomina in bepaalde gevallen interrogatieve, in andere indefiniete betekenis hebben. De stand van mijn syntactisch onderzoek van het Javaans maakt dat een beschrijving van deze gevallen niet meer dan een zeer voorlopige kan zijn.

De interrogatieve betekenisonderscheiding wordt geactueerd:

1. indien het pronomen het laatste woord van de zin vormt;

2 . indien het pronomen met een zelfstandig naamwoord een woordgroep vormt die tezamen met een al of niet samengestelde woordgroep het gehele woordmateriaal van de zin omvat;

3. indien het pronomen met een al of niet samengestelde woordgroep een groep vormt die het gehele woordmateriaal van de zin omvat. 


\begin{tabular}{|c|c|c|c|c|c|c|}
\hline छ & & & & & 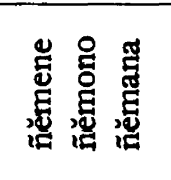 & 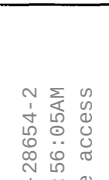 \\
\hline छั่ & 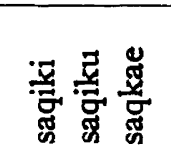 & 111 & 111 & 111 & 111 & 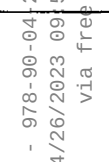 \\
\hline 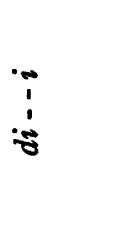 & 111 & 111 & 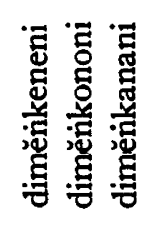 & 111 & 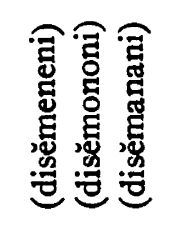 & 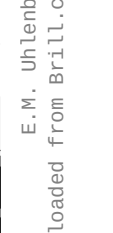 \\
\hline 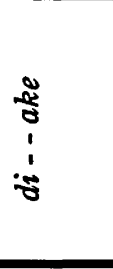 & 111 & 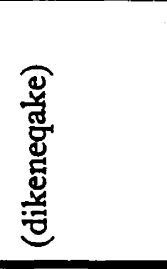 & 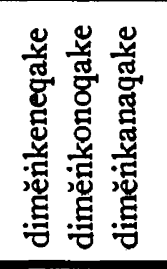 & 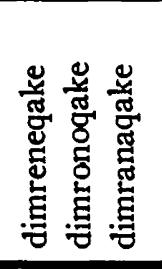 & 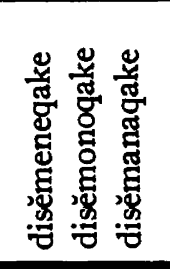 & 言 \\
\hline 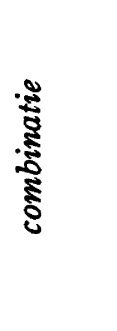 & 苞 & 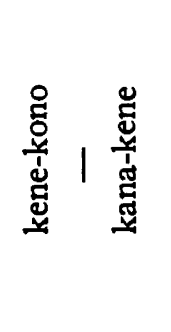 & 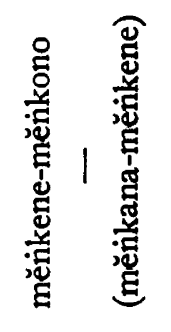 & 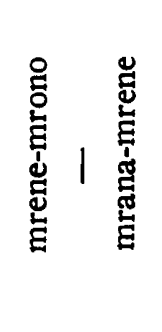 & & 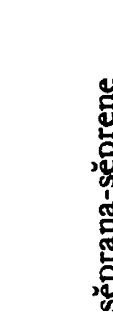 \\
\hline 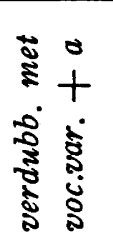 & 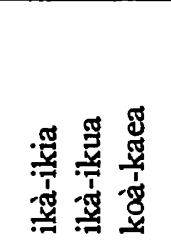 & 111 & 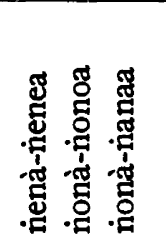 & 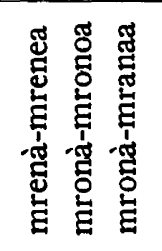 & & \\
\hline 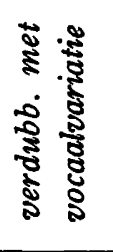 & 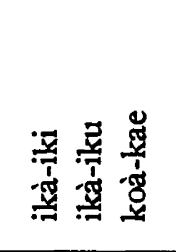 & 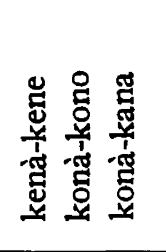 & 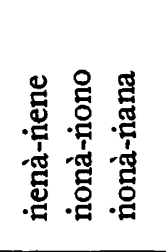 & 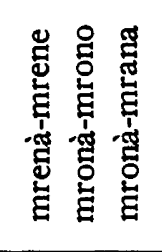 & 111 & \\
\hline हैं & $1 \mid \frac{\mathscr{\mathbb { g }}}{\dot{\sharp}}$ & 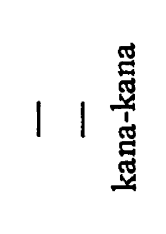 & 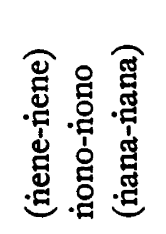 & | | | & | 1 | & 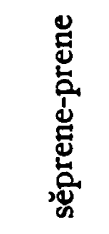 \\
\hline ₹ & 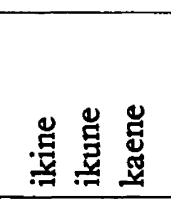 & 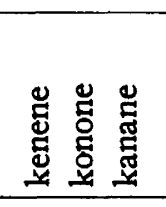 & 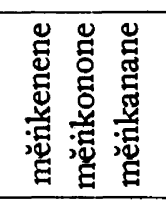 & 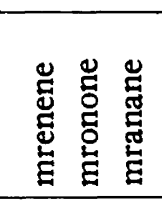 & 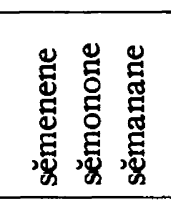 & \\
\hline & & & 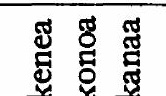 & \& & ฐ & \\
\hline
\end{tabular}


E.M. Uhlenbeck - 978-90-04-28654-2 Downloaded from Brill. come4/26/2023 09:56:05AM via free access 


\begin{tabular}{|c|c|c|c|c|c|}
\hline I & II & III & IV & V & VI \\
\hline $\begin{array}{l}\text { sapa, wie } \\
\text { sintěn }\end{array}$ & $\begin{array}{l}\text { sapaa } \\
\text { sintěna }\end{array}$ & $\begin{array}{l}\text { sapa-sapa } \\
\text { sintěn-sintěn }\end{array}$ & $\begin{array}{c}\text { sapa ta sapa } \\
\text { sintěn ta } \\
\text { sintěn }\end{array}$ & $\begin{array}{l}\text { sopà-sapa } \\
\text { sintan-sintěn }\end{array}$ & $\begin{array}{l}\text { sapa-sapaa } \\
\text { sintěn- } \\
\quad \text { sintěna }\end{array}$ \\
\hline $\begin{array}{ll}\text { apa, } & \text { wat } \\
\text { napa } \\
\text { punapa }\end{array}$ & $\begin{array}{l}\text { apaa } \\
\text { napaa } \\
\text { punapaa }\end{array}$ & $\begin{array}{l}\text { apa-apa } \\
\text { napa-napa } \\
\text { punapa- } \\
\quad \text { punapa }\end{array}$ & $\begin{array}{c}\text { apa ta apa } \\
\text { napa ta napa } \\
\text { punapa ta } \\
\text { punapa }\end{array}$ & $\begin{array}{l}\text { opà-apa } \\
\text { nopà-napa } \\
\text { punàpà- } \\
\quad \text { punapa }\end{array}$ & $\begin{array}{l}\text { apa-apaa } \\
\text { napa-napaa } \\
\text { punapa- } \\
\text { punapaa }\end{array}$ \\
\hline $\begin{array}{ll}\text { ĕndi, welk, } & \text { waar } \\
\text { pundi }\end{array}$ & $\begin{array}{l}\text { ěndia } \\
\text { pundia }\end{array}$ & $\begin{array}{l}\text { ĕndi-ĕndi } \\
\text { pundi-pundi }\end{array}$ & $\begin{array}{l}\text { ĕndi ta ěndi } \\
\text { pundi ta } \\
\text { pundi }\end{array}$ & $\begin{array}{l}\text { ěndà-ěndi } \\
\text { pundà-pundi }\end{array}$ & $\begin{array}{l}\text { ěndi-ěndia } \\
\text { pundi-pundia }\end{array}$ \\
\hline $\begin{array}{l}\text { kĕpriye, hoe } \\
\text { kĕpripun } \\
\text { kadospundi }\end{array}$ & & $\begin{array}{l}\text { kěpriye- } \\
\text { kěpriye } \\
\text { kěpripun- } \\
\text { kěpripun } \\
\text { kadospundi- } \\
\text { kadospundi }\end{array}$ & $\begin{array}{c}\text { kěpriye ta } \\
\text { kěpriye }\end{array}$ & $\begin{array}{l}\text { kěpriyà- } \\
\text { kěpriye } \\
\text { kěpripan- } \\
\text { kěpripun }\end{array}$ & \\
\hline $\begin{array}{ll}\text { pira, hoe- } & \text { veel } \\
\text { pintěn } & \end{array}$ & $\begin{array}{l}\text { piraa } \\
\text { pintěna }\end{array}$ & $\begin{array}{l}\text { pira-pira } \\
\text { pintěn-pintĕn }\end{array}$ & $\begin{array}{l}\text { pira ta pira } \\
\text { pintěn ta } \\
\text { pintĕn }\end{array}$ & $\begin{array}{l}\text { pirà-pira } \\
\text { pintàn- } \\
\quad \text { pintĕn }\end{array}$ & \\
\hline $\begin{array}{r}\text { kapan, wan- } \\
\text { neer }\end{array}$ & kapana & kapan-kapan & $\begin{array}{l}\text { kapan ta } \\
\text { kapan }\end{array}$ & kapan-kepen & $\begin{array}{l}\text { kapan- } \\
\text { kapana }\end{array}$ \\
\hline
\end{tabular}

De indefiniete betekenisonderscheiding wordt daarentegen geactueerd, wanneer het pronomen deel uitmaakt van een woordgroep, die zelf weer lid is van een meeromvattende woordgroep. Schematisch kan aldus het verschil worden aangegeven $(\mathrm{W}=$ woordgroep die het totale woordmateriaal van de zin vormt, $\mathrm{w}=$ woordgroep, $\mathrm{p}=$ pronomen van kolom 1).

\begin{tabular}{|c|c|}
\hline $\begin{array}{c}\text { met interrogatieve } \\
\text { betekenis }\end{array}$ & $\begin{array}{c}\text { met indefiniete } \\
\text { betekenis }\end{array}$ \\
\hline
\end{tabular}


Met vragende betekenis kunnen de pronomina zowel staan in beginals in eindpositie: apa sin koqgawa? wat heb je meegebracht? kan in gelijke betekenis voorkomen naast sin koqgawa apa? In het geval waarin $a p a$ het laatste woord van de zin is, is $a p a$ altijd vragend. Begint de zin echter met $a p a$, dan kàn $a p a$ interrogatieve betekenis hebben, maar ook indefiniete, bijv. apa sin koqgawa, měsți dirěbut, wat je bij je hebt, zal je zeker afgenomen worden.

Gevallen van gebruik van de pronomina met actuering van de interrogatieve betekenis :

1. won tuwane Maryam arěp ñlamĕti sapa? (SB Ib 49, 10), voor wie wilden de ouders van Marjam een slametan geven?

lurah sapa sin ora těka? (Sg), welke lurah is niet gekomen?

2. pagaweanmu apa? běrah-běrah; buruh apa, buruh měñà i்ěndi? (BD 25, 7-5 v.o.), wat is je werk? Ik werk hier en daar (in loondienst). Wat voor loondienst, waar werk je?

omah apa sin koboin? (Sg), wat voor huizen zijn verbrand?

3. Karman pitakon: ěndi macane? (KA 23, 16), Karman vroeg: waar is de tijger?

omah ěndi sin kobon்? (Sg), welke huizen zijn verbrand?

4. lah krěsane kĕpripun? (K 1250, 1, 15 v.o.), nu, wat is zijn bedoeling? omah kěpriye sin kobon'? (Sg), wat voor soort huizen zijn verbrand?

5. aingone bubaran wayah jam pira? (SB IIa 69, 17), om hoe laat gingen zij uiteen?

omah pira sin koboin? (Sg), hoeveel huizen zijn verbrand?

6. olehe boyon mrono besuq kapan? (SB IIa 54, 5 v.o.), wanneer gaan ze daarheen verhuizen?

dina kapan těkane? (Sg), welke dag komt hij ?

Gevallen van gebruik van de pronomina met actuering van de indefi. niete betekenisonderscheiding :

1. wohe, ta, olehe nděměnaqake patin grandul; sapa wěruh, ya kěmĕcĕr nilěr, kudu manan (KA 58, 13-14), die vruchten zeg, wat aantrekkelijk waren ze (zoals) ze daar hingen; wie ze zag, moest ervan watertanden (en) moest er wel van eten. 
2. ... mila sapunika ugi kula bade ṅaturakĕn punapa saraosin manah kula (WG 43, 25-26), daarom zal ik nu ook zeggen wat al de gevoelens van mijn hart zijn.

3. mulane wizert saiki uga, kowe nitenana ëndi pan்gulawẹnțah kai ora prayoga, lan éndi kaì prayoga (SS 72,1-3), daarom, van dit ogenblik af moet gij onderzoeken welke opvoeding de verkeerde is en welke de goede.

4. ...prĕlu dikon nonton kĕpriye kaanane won-won sin arĕp pada pindah ñan tanah sabrain (BD 176, 16-17), . . omdat ik moet gaan zien in welke toestand de mensen verkeren die willen emigreren naar het land aan de overwal.

5. sarta saka sasrazeniane saběn dina iya wěruh pira pañasilane kaum dagain (BD 172, 4-2 v.o.), en door haar dagelijkse omgang (met hen), weten zij ook hoeveel de handel verdient.

6. yen ana sin wani takon kapan marine, Martin bañjur nĕsu (K 1249, 2, 27-28), als er iemand is die durft te vragen wanneer hij beter zal zijn, dan wordt Martin boos.

De pronomina van de tweede kolom, sapaa c.s. verschillen in betekenis van sapa-șapa c.s., door het hypothetische betekeniselement dat zij bevatten: wie zou er kunnen zijn $\rightarrow$ er kan niet iemand zijn $\rightarrow$ niemand: sapaa ta sin ora nĕsu, yen tansah digoda wae (SlR), wie zou er kunnen zijn die niet kwaad werd d.w.z. wie zou niet kwaad worden, als hij voortdurend geplaagd wordt. Andere gevallen van gebruik: kaya apaa rupane, won் anaq, měsți ditrěsnani (Sg), hoe ook zijn uiterlijk moge zijn, het is immers (zijn) kind, ongetwijfeld zal hij ervan houden; sarerise lesus gĕde mĕnḍa, ěndia sin didělĕn měsți katon karusaqan ruparupa $(\mathrm{Sg})$, nadat de zware storm was gaan liggen, zag men waar men ook maar keek allerlei dat beschadigd was; bara $\dot{n}$-baran sin arĕp digawa kabeh dicěpaqake, kapana montor sin mĕtuq těka, engal maìkat (Sg), alles wat meegenomen zal worden, wordt gereed gezet, (zodat) wanneer maar de auto die het komt afhalen, arriveert, men snel weg kan; si Karta tekade kudu nduweni omah kuwr, piraa rĕgane saguh nuku (Sg), Karta was vast besloten om dat huis te krijgen, hoeveel ook de prijs zou zijn, hij was bereid het te kopen.

Van de pronomina van de derde kolom betekent sapa-sapa, al wie; $a p a-a p a$, iets wat ook; ěndi-ěndi, welke ook, waar ook; kĕpriye-kĕpriye, hoe ook, op enigerlei wijze; pira-pira, ettelijke, een onbepaald aantal, en kapan-kapan, bij een of andere gelegenheid. In vergelijking met de 
pronomina van de eerste kolom missen zij dus iedere interrogatieve betekenis. $Z$ ij zijn emfatische indefinita. Gevallen van gebruik:

1. kanți ora mrĕduli sapa-sapa, aku bañjur bĕstel bae (OP 21, 8-9), zonder me om wie ook te bekommeren, bestelde ik maar.

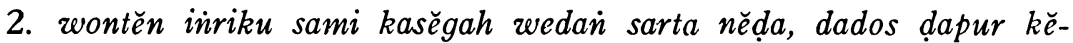
lěrěsan, jalaran ankatipun sakin griya sami derén punapa-punapa (MMTj I 13, 8-6 v.o.), daar kregen we wat warms te drinken en wat te eten, en dat trof dus eigenlijk wel goed, want bij ons vertrek van huis hadden we nog niets (wat ook) gehad.

3. ... in salajěniipun ndlidir kemawon datěniipun arta darma sakin in pundi-pundi (PPT I 16,1-2), vervolgens stroomden de gaven in geld binnen van alle kanten (van overal).

4. olehe sudi, ora jalaran saka kĕpriye-kĕpriye, naniin jalaran saka kabutuh (PPB 41, 6-4 v.o.), dat zij er toe bereid zijn dat komt niet door welk motief ook, maar doordat zij het moeten.

5. upas Suradinama mangih sĕrat gantosan pintěn-pintĕn kaslëmpitakĕn wontěn in usuq (Skt 42, 9-8 v.o.), de agent Suradinama vond ik weet niet hoeveel pandbriefjes die tussen de binten van het dak gestoken waren.

6. neq aku iki gampan, diějaq kapan-kapan, rěbo utawa kĕmis iya

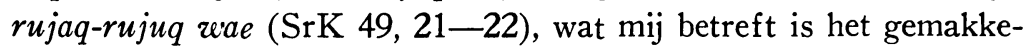
lijk, op welk tijdstip ik ook uitgenodigd word, woensdag of donderdag, daar ga ik allemaal mee accoord.

De vormen van de vierde kolom staan in betekenis zeer dicht bij die van de tweede. $\mathrm{Zij}$ komen vooral in de spreektaal voor en bevatten zoals wij elders reeds opmerkten 35 een affectief moment dat aan de formatie zonder $t a$ niet eigen is; zo betekent: apa ta apa, wat ook, het kan me niet schelen wat, bijv. adate bocah loro iku yen dolan měñan kĕbon karo goleq apa ta apa sin kĕna dipanan (KA 39, 21-22), gewoonlijk zoeken de twee jongens wanneer ze in de tuin spelen, naar alles wat ze ook maar kunnen eten. Op basis van de corresponderende krama-pronomina kunnen deze $t a$-verdubbelingen niet gevormd worden. Ook met het nadruk leggende $t a$ alleen komen sapa, $a p a$, ěndi, kĕpriye, kapan en pira veelvuldig verbonden voor: sapa ta kuwi (BD 135, 8 v.o.), wie is dat toch?; napa ta, napa (BD 135, 19), wat dan, wat?; pripun ta, kyaine, dinaqi lazeain napa botĕn? (BD 136, 1), hoe nu, man, moet de deur open of niet?

35 BKI 109 (1953), p. 371. 
Met vocaalvariatie verdubbelde vormen heb ik in teksten niet aangetroffen. Dat ze in de gesproken taal regelmatig voorkomen staat echter volkomen vast. Zoals ik vroeger 36 reeds heb opgemerkt komen bij het vocalisme $a-a$ soms twee vormen voor die semantisch van elkaar verschillen. Ik noemde zo opà-apa tegenover $a p a-e p e$. Of evenwel altijd twee vormen bij $a-a$ vocalisme voorkomen is de vraag. Naast sopà-sapa komt voor zover we hebben kunnen vaststellen, niet sapa-sepe voor; naast kapan-kepen, niet kopan-kapan. De emotionele waarde van deze formatie blijkt duidelijk uit de volgende zin: hus, aja sopà-sapa takon jëněne dayoh sin těka, aku dewe akeh ora wanuh $(\mathrm{Sg})$, stil, vraag toch niet alsmaar naar de namen van de aankomende gasten, velen ervan ken ik zelf niet.

De zesde kolom bevat de verdubbelingen met suffix $-a$. De frequentie van dit soort vormen is in teksten niet hoog; zij schijnen overigens wel in de sapa-, apa-, éndi- en kapan-reeks te kunnen voorkomen. Misschien komt ook pira-piraa voor. De gevallen uit teksten opgetekend zijn gering (4).

Het betekenisverschil tussen de vormen van de tweede en de zesde reeks is een verschil in intensiteit en affectiviteit. Van de gevallen waarin ik de krama-vorm sintěn-sintěna aantrof, vermeld ik: sintěnsintěna neq turu mĕsți ěngih kĕpenaq? (OOA 13, 7-6 v.o.), iedereen, wie ook maar, heeft 't, als hij slaapt, toch naar zijn zin?; $\dot{n}$ gih sakin sintěn-sintěna mĕnika, botěn pĕrlu sampeyan ìëndikaqake, kula botĕn bade maelu, areit botěn ontěn damĕle (SW 4/5), van wiens kant het ook komt, $\mathrm{u}$ behoeft het niet te zeggen, ik zal me er niet mee inlaten, omdat het geen nut heeft. In deze zinnen zou de vorm sintěna zeer goed mogelijk zijn; dan is er echter geen emotionele geladenheid.

\section{Afkortingen, transpositiemogelijkheden en verdere bijzonderheden}

\section{A. S a a}

De enige transpositiemogelijkheid die sapa (en krama sintěn niet) vertoont is dezelfde welke ook bij de pronomina personalia voorkomt nl. naar de verba door nasalering c.q. prefigering van $d i$ - in de betekenis van vragen wie iemand is, iemand aanspreken. Deze uit transpositie ontstane verba hebben geen afzonderlijke krama-vorm naast zich. Enige

36 De structuur enz., p. 223. 
gevallen van gebruik: kula ñapa, naìin piyambaqipun botěn mañsuli (PPT I, 10), ik vroeg wie hij was, maar hij antwoordde niet; lare ler

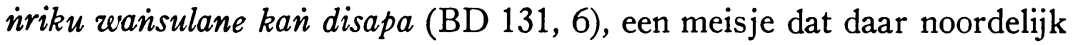
van $u$ woont, antwoordde degene aan wie gevraagd werd wie zij was. Ook de andere normaal te verwachten verbale vormen doen zich voor ${ }^{37}$ : la punika tiyaì sažĕg sami grombolan, kulasapanipun: Sapa ya? (SK 86, 15-17), hé daar staan juist mensen bijeen, ik zal ze eens vragen wie ze zijn: wie zijn jullie? Of sapane voorkomt is waarschijnlijk, maar toch niet zeker, aangezien mij geen gevallen uit teksten bekend zijn en de mededelingen van mijn informanten niet congruent zijn. Sapane zou zijn een meer nadrukkelijke vorm, analoog aan formaties als kenene, die bij de pronomina demonstrativa voorkomen, zo bijv. sapane ta sin dirěmbug (SIR), over wiè wordt gesproken. Of een verdubbeling sapa-sapane mogelijk is, is mij onbekend.

Met $a k u$ en korve heeft sapa een personaal betekeniselement gemeen. Het vraagt uitsluitend naar personen, nooit naar zaken.

Afkortingen en madya-vormen komen niet voor. De dialectische vorm sapa-sintěn voor sapa-sapa die de woordenboeken en ook Kiliaan vermelden, was aan mijn informanten onbekend. In de door mij geraadpleegde moderne teksten ben ik haar nimmer tegengekomen.

\section{B. A pa}

Wellicht van alle pronomina, maar zeker van alle pronomina interrogativa et indefinita komt het neutrale ,merkmallose” $a p a$ in dialogen het meest voor. Het wordt nl. als enige van de zes pronomina van de eerste kolom gebruikt als algemeen vraagwoord, zo bijv. apa iya ta, Pon? (PPB 32, 3), is dat werkelijk zo, Pon? In dergelijke zinnen kan men, wanneer men de intonatie gelijk houdt, het woord $a p a$ zonder bezwaar weglaten: iya ta? is dat zo?, komt in gesprekken even veelvuldig voor als apa iya ta? Als algemeen vraagwoord is apa uiterst mobiel. Alle 6 mogelijke volgorden komen voor.

(1) apa iki bĕnĕr?

(2) apa bĕnĕr iki?

(3) iki apa bĕnĕr?

(4) iki bĕnĕr apa?

(5) bĕnĕr apa iki?

(6) bĕnĕr iki apa?

37 For Roman Jakobson 1956, p. 570. 
Hiernaast kunnen dus ook nog zonder $a p a$ en met verschillende intonatie zowel $i k i$ bĕnĕr? als bĕnĕr $i k i$ ? voorkomen. Een beschrijving van het betekenisverschil dat er tussen deze zinnen bestaat, kan alleen geschieden wanneer men ook de verschillende intonatiepatronen aangeeft die hier mogelijk zijn. Dit valt echter buiten het bestek van dit werk.

Evenals de corresponderende $i k i$-serie uitgebreidere bespreking verlangde dan de andere demonstrativa, zo dient op allerlei gebruik van $a p a$ hier nog gewezen te worden, dat nog niet in de algemene paragraaf over de categorieën aan de orde is gekomen.

Behalve de mogelijkheden van gebruik, die hierboven vermeld zijn, kent $a p a$ nl. nog de volgende gebruikswijzen:

1. Apa niet met andere woorden verbonden, vaak het totale woordmateriaal van de zin uitmakend. Hiertoe behoren twee gevallen: exclamatief $a p a$, wat! met sterk stijgende intonatie, meestal als uiting van boosheid of ergernis, zo bijv.: ... malah saya marah-marah, kandane:

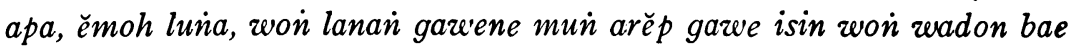
(BD 152, 3-4), zelfs werd ze hoe langer hoe bozer, ze zei: Wat! wil je er niet heengaan! mannen doen niets anders dan hun vrouwen te schande maken. Daarnaast is het informerende apa? wat?, wat bedoel je? met sterk stijgende intonatie $(/)$ frequent in gebruik, wanneer men de spreker niet verstaan of begrepen heeft, bijv. BD 133, 10 v.o. waar de vrouw van de modin zegt als ze buiten weer kula nurwun hoort roepen: hara ta, turene botěn bali, wel verdraaid, hoor nou es en je zei nog wel dat ze niet terug zouden keren, en de modin niet direct de reactie van zijn vrouw begrijpt en antwoordt: apa?, wat bedoel je?

2. Apa met de betekenis: hoe zou ik!, denk je soms dat ik ..., bijv. ñjërita, apa aku wědi (GW I 23, 15), schreeuw maar, denk je dat ik bang ben! Apa kan in dit soort gevallen niet staan in eindpositie. De enige andere mogelijkheid van woordvolgorde met behoud van het karakter van dit type retorische vraag is : aku apa wědi.

3. Apa in zinnen die een alternatief stellen, dit of dat, al of niet, bijv. sin dikĕrsaqake apa, kopi apa teh? (MMTj 23, 10 v.o.), wat wenst u, koffie of thee?; apa gětih kañ rerata ana in sajronin kamar Kiranapuran iku gĕtihe kanimas Santosa apa dudu (Skt 36, 8-7 v.o.), of het bloed dat overal verspreid is in de kamer van $\mathrm{K}$. is dat het bloed van (broer) Santosa of niet? In dit soort gevallen staat $a p a$ altijd voor het woord of de woordgroep die het tweede deel van het alternatief formuleert.

4. Apa om extra reliëf te geven aan het onmiddellijk voorafgaande 
woord; er komt door dit $a p a$ ook een zekere emotionaliteit in de zin, bijv. lah iki apa tikuse (SB IIa 17, 2), daar heb je nou de muis; lah kae apa layanane pijër edeg ora uzis-uwis (BD 53,6), ha daar ginds is $z$ 'n vlieger die steeds maar heen en weer gaat; lah kae apa $(\mathrm{Sg})$, ha daar heb je hem nou eindelijk! (bijv. iemand op wie men lang gewacht heeft en die men nu eindelijk, geërgerd of met vreugde ziet aankomen).

5. Apa in slotpositie in vraagzinnen met de betekenis : of zo: $a p a$ dikira yen aku ora duwe duwit apa (BD 140,15), denkt hij soms dat ik geen geld heb of zo? Terwijl $a p a$ in gewone vraagzinnen als akeh won lara apa?, veel mensen waren waaraan ziek?, de intonatie middenlaag-hoog ( $)$ is, blijft in deze zinnen de intonatie zonder voorafgaande daling stijgen.

Wellicht moet tenslotte nog een 6de geval worden onderscheiden, waarin $a p a$ eveneens in slotpositie voorkomt; $a p a$ wijst dan op een zeker ongeloof of gevoel van ongeduld bij de spreker, zo bijv. sabarsabar napa; elin-elin napa (K 1249, 2, 11 v.o.), wát geduldig! wát indachtig!; sugih napa, won nika olehe ñapusi (GW II 31, 10), wat rijk? dat geld heeft hij immers gekregen door bedrog. Het is evenwel ook mogelijk dat dit niet anders zijn dan varianten van geval 1 (met plaatsing van $a p a$ achter in plaats van vooraan in de zin).

In al deze gevallen correspondeert met $a p a$ in het krama měnapa. Er is echter een geval van gebruik van mĕnapa dat niet met $a p a$, maar met barain correspondeert. Bijv. ...lare-lare inka $\dot{n}$ wontěn pasarean in Giri panĕdanipun mĕnazei botěn dipunsukani purun mĕmisuh punapa (BD 2, 5-7), de kinderen op de begraafplaats van Giri, wanneer ze op hun vragen niets krijgen, wagen ze het zelfs om je uit te schelden; salěbĕtin griya prabotipun pinangih sarwa mĕpĕki, malah caranï dusun makatěn, pinaingih ragi aneh, mawi gadah brandkas punapa (SK 5, 19-21), in het huis was de inrichting geheel compleet, zelfs wat voor een desa wat vreemd aandeed, hij had er nog een brandkast bij. Bij omzetting in het ngoko zou punapa vervangen moeten worden door baran en niet door $a p a$.

Niet geheel duidelijk is mij verder het gebruik van het niet vragende $a p a$ in slotpositie voorafgegaan door tiq (= katiq), zo bijv. $e$, dadi kowe sěnĕn ñan Karman karo ñan aku? Ya wis, aku nanis tiq apa (KA 19, 7-6 v.o.), o, dus je vindt het prettiger met Karman dan met mij ? Nou, dan ga ik huilen hoor (zegt de spreekster pruilend, mokkend). Het lijkt er dus op dat $a p a$ ook in indefiniete betekenis in bepaalde gevallen aan het einde van de zin kan staan en dus een uitzondering vormt op de in de vorige paragraaf geformuleerde regel. 
Apa komt voorts frequent in verschillende vaste combinaties voor. Evenals alle andere pronomina van deze groep kan $a p a$ verbonden worden met $t a, a p a t a$, wat toch, wat toch wel. Evenals sapa en ěndi kan $a p a$ met bae of wae verbonden worden: apa bae kan katon, alles wat ook maar te zien is. Evenals sapa en kĕpriye wordt het verbonden met voorafgaand (niet noodzakelijk direct voorafgaand) geq, wat is dat toch, bijv. geq apa wohe tatanan kain kaya maikono mau (BS 47/48), wat is toch het resultaat van die regeling? Vaak treedt ook geq apa ta op. Met ěndi deelt $a p a$ de mogelijkheid van combinatie met ana, welke combinatie dezelfde betekenis heeft: hoe is het mogelijk, hoe bestaat het! bijv. karěpku supaya nuli nduzeni kěndaq, apa ana mandaq saya luna tanpa pamit (SR 65, 1-2), mijn bedoeling was, dat hij zijn leven beterde (zich matigde), maar hoe is het mogelijk, hij is zelfs weggegaan zonder afscheid te nemen. De enige combinatie van pronomina van deze groep is tenslotte apa piye, of hoe is het (ook weer), of hoe zit het, dat in gewone conversatie uiterst frequent is, evenals apa kuzw, dat eveneens veelvuldig gebruikt wordt wanneer men aarzelt of naar zijn woorden zoekt.

Op basis van $a p a$ zijn verschillende formaties mogelijk.

1. Napa, wat doen?, bijv. ěmboq takon : lagi pada napa ta? Daqtiliqi, lagi pada pěrañ-pĕrañan (SB Ib, 16, 7-6 v.o.), moeder vraagt: wat zijn ze aan het doen? Ik ga eens kijken, ze zijn aan het oorlogje spelen; Slamĕt napa (SB IIa, 17, 1 v.o.), wat doet Slamet? Of de vorm diapa voorkomt is uiterst onzeker; in teksten trof ik cleze vorm niet aan tot dusverre.

Ook treedt $\dot{n} a p a$ in bepaalde collocaties op als variant van apa zonder betekenisverschil (dikaya apa naast dikaya napa; ora dadi apa naast ora dadi íapa). Er is echter ook nog een ander geval. In de zin lo, lah napaa botěn (BD 136, 13), hé, waarom zou ik het niet (durven), als antwoord gegeven op de vraag kowe wani mlěbu niomah apa ora?, durf je het huis binnen te gaan of niet? kan de madya-term napaa wel bij gebruik van ngoko vervangen worden door íapaa maar niet, voorzover wij hebben kunnen vaststellen, door apaa. Het woordenboek van Pigeaud vermeldt echter wel apaa (gespeld apaha). Dit $\dot{n} a p a a, \mathrm{kr} . m \check{e}-$ napaa (bij Pigeaud gespeld punapaha) betekent: hoe, waarom toch, hoe zou toch, bijv. napaa kowe biyen ora tutur aku (Sg), waarom toch heb je het me toen niet gezegd?

2. Apane, apaku, apamu. Ook hier is er duidelijk transpositie naar de substantiva. Deze vormen zijn frequenter dan welke andere -ne vorm ook in deze groep pronomina. Enkele gevallen van gebruik: apaku ta sin 
mĕdeni, koq bocah-bocah pada wĕdi karo aku (TB 100, 1, 4-5), wat toch aan mij is vreeswekkend, dat de kinderen waarachtig allen bang voor mij zijn; apane sin durun ganěp (BD 127, 6), wat er van is nog niet compleet (nl. van het geleende huisraad). Enigszins anders is het gebruik in zinnen als: Din, gripmu apa wis diasah? eh, apane sin wis diasah? ( $\mathrm{Sj}$ ), Din, is je griffel al geslepen? Hè, van wat vraag je of het al geslepen is? (de hoorder heeft niet precies de vraag gehoord). Ook wordt apane vaak gebruikt wanneer naar familieverhoudingen wordt gevraagd, bijv. sampeyan kaprěnah napane Kartadipa? (BD 78, 20), wat ben je van Kartadipa?

Op dezelfde wijze komt van $a p a-a p a$ de vorm apa-apane voor (krama mĕnapa-mĕnapanipun): dados manawi panajaran luhur in tanah iriki punika punapa-punapanipun sagěd dipunakĕni saenipun datěn liya nagari,... (K 1220, 2, 13-11 v.o.), dus indien van het hoger onderwijs hier te lande in alle opzichten de deugdelijkheid werd erkend door andere landen,...

Ook saapa-apane (kr. saměnapa-mĕnapanipun), met alles wat er van is, in alle opzichten, eveneens een geval van transpositie, vindt men

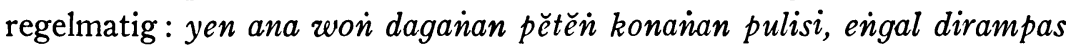
saapa-apane pisan, tur wone dikuñjara (Sg), als iemand zwarte handel drijft en door de politie betrapt wordt, dan wordt alles wat hij heeft, verbeurd verklaard en de man gevangen gezet; won iya luwih saapaapane (TB 7, 1, 13), immers hij was uitstekend in alle opzichten.

3. Verder moet geacht worden als direct door transpositie van $a p a$ gevormd : napaqake/dikapaqake (krama: měnapaqakĕn/dipunměnapaq$a k e \check{n}$ ) waarnaast ook de verdubbelde vorm dikapaq-kapaqake regelmatig voorkomt: ya ayua kaya setan kae, neq aku ěmoh, arěp dikapaqake (WG $15,2)$, ook al is ze zo knap als een duivelin, als ik geen zin in haar heb, wat wil je er dan aan doen?; Pon mansuli: ya wis, neq ora nakal iya ora taqkapaq-kapaqake (PPB 5, 17-18), Pon antwoordde: Nu goed, als hij niet stout is, dan zal ik heus niets wat ook maar doen; ěmpun, ěmpun, kapaq-kapaqna won wis kalah (ER 58, 1, 3-2 v.o.), goed, goed, je hoeft niets tegen me in te brengen, immers ik heb het toch al verloren.

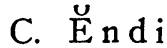

Met de vermelding van het tweeërlei gebruik van ĕndi, waar, in de algemene paragraaf over de categorieën is het gebruik van ěndi eveneens nog niet volledig beschreven. Op vier gebruiksmogelijkheden moet nog gewezen worden: 
1. in vergelijkingen: besuq olehmu gawe omah gĕde ĕndi karo omah kene, paq? (AMK 27, 10-11), later als u een huis gaat bouwen, welk huis zal dan groter zijn, het (nog te bouwen) huis of dit hier (wat we nu hebben), vader?

2. in zinnen die een uitdrukking zijn van ongeloof: ěndi won bisa digugu yen omone bolaq-baliq (SIR), hoe zou je iemand kunnen geloven als hij elke keer wat anders zegt; ̌̌ndi adus tanpa sabun, hoe kun je baden zonder zeep. Frequenter dan dit ĕndi alleen is de groep ěndi ana of ïĕndi ana (krama: pundi wontěn, madya: pundi entěn): pundi entěn, kula gěnti botĕn niandĕl (OOA 13, 2 v.o.), hoe kan dat nou, nu geloof ik het op mijn beurt niet.

3. in zinnen van het type ěndi sin... ěndi sin..., nu eens dit, dan weer dat: neq pinuju ora ìgarap sazeahe iya ora tau nàngur, ěndi sin ṅanam tepas, ěndi sin gawe irus, parut utazea liyane (AMK 7, 10—7 v.o.), als ze eens niet de sawah bewerkten, dan zaten ze niet ledig, nu eens vlochten zij vuurwaaiers, dan weer maakten ze scheplepels, raspen e.d.; wizwit maìkat tibane pěcut wis ora ana lerene, ěndi sin gĕgěr, ěndi sin rai, ěndi sin sikil (PPB 42, 8-10), vanaf het vertrek viel de zweep onophoudelijk (op mij), nu eens op de rug, dan weer op het gezicht, dan weer op mijn benen.

4. in de betekenis van: geef hier! geheel te vergelijken dus met het overeenkomstig gebruik van kene: ěndi, $y u$, ěndi, $y u, a k u$ sin nunganii ěndi, ěndi! (LBK 15, 3-4), geef hier, zus, geef hier, zus, ik wil er op rijden. Geef hier! Geef hier! Soms volgt op ěndi, kene bijv. ěña! ěndi kene aku dagine (KA 5, 3 v.o.), hier (asjeblieft), (maar) geef hier, ik het vlees (bij het elkaar betwisten van een stuk kip).

Evenals bij kene, kono en kana is de combinatie met de prepositie $i \dot{n}$ bijzonder frequent; in ěndi, waar, wordt vaak verkort tot $\dot{n} \breve{n} n d i$, zoals naast inriki, als krama van in kene, regelmatig nriki voorkomt. Zoals opgemerkt is, bestaat er geen speciaal pronomen interrogativum dat met de mrene-serie correspondeert; in plaats daarvan treedt op de

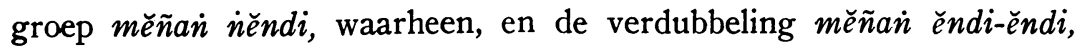
overal heen waar ook maar.

Hoewel wij geen gevallen van gebruik in teksten van ěndine hebben gevonden, achten wij de aanwezigheid van een dergelijke vorm niet uitgesloten, vooral ook niet omdat ěndi-ěndine schijnt voor te komen: omahe taqdĕlěñ ěndi-ěndine rěsiq $(\mathrm{Sg})$, ik zag dat alles van het huis schoon was. 
D. Kĕpriye

Met kĕpriye, hoe, correspondeert in de standaardtaal kadospundi, in vlotte spreektaal afgekort tot dospundi: paqne, paqne, niki, anaq sampeyan dospundi (BD 130, 22-23), vader, vader, wat is er met onze dochter? Daarnaast komt de vorm kĕpripun (verkort pripun, dat als madya-vorm geldt) voor, die niet alleen dialectisch krama is maar ook gebruikt wordt daar waar de vorm kadospundi te formeel, te deftig zou zijn. Këpriye zelf wordt meestal verkort tot priye en piye en heeft een zeer hoge gebruiksfrequentie, o.a. doordat het door velen als een soort stopwoordje wordt gebruikt, bijv. wanneer men aan het vertellen is en men even tijd wil winnen, omdat men niet weet hoe men verder moet gaan; vaak wordt dit dan verbonden met $t a$ naar we hierboven reeds opmerkten en is dan weer te geven met: nou, hoe zit dat, o.i.d. Zo bijv. $e$, piye ta, mbaqyu ki, peh gunĕman ana pasar we daraqi goroh (SW 25, 18-19), zeg hoe zit dat nu (met jou) zus, omdat we nu maar op de pasar er over praten, denk je dat het onwaarheid is.

In gesprekken veelvuldig voorkomende woordgroepen met kĕpriye zijn voorts: 1) geq kĕpriye ta, hoe moet het toch ( $O$ Allah, Sin, geq kĕpriye ta, won kene ora ana pĕladen sin kĕna dipracaya ... (BD 123, 15-16), O, God, Sin, hoe moet dat nu, er is immers hier geen bediende aan wie men het kan toevertrouwen); 2) witiqna kĕpriye, hoe anders, hoe dan (witiqna kĕpriye? won anaq, neq dudu won tuwane sin̈ $\dot{n} g o l e q-$ ake kapintěran, geq sapa? (AMK 23, $7-6$ v.o.), maar wat wil je, immers voor kinderen, als de oùders niet voor hun opleiding zorgen, wie zal het dan doen?) en vooral 3) $a p a p(r) i y e$, vaak aan het eind van een zin, in de betekenis: of hoe dan (lo, koq kowe, Din, diutus ndaramu apa piye? (GW I 17, 10 v.o.), hé jij daar, Din, ben je gezonden door

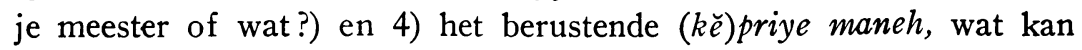
men er aan doen, wat wil je er aan doen, bijv. nainin kĕpriye maneh, atine wis notol bae (AMK 63, 12), maar wat kan men er aan doen, zijn hart zet hem maar steeds (daartce) aan.

De enige formatie die op basis van kĕpriye voorkomt, is die met suffix -ne. Of een corresponderende krama-vorm met -nipun bestaat of te vormen is, is mij niet bekend. De vorm kĕpriyene, het hoe er van, is als een geval van transpositie naar de substantiva te beschouwen, analoog aan het hierboven besproken apane en het hieronder nog te noemen pirane. Een geval van gebruik: bab ingonku nuluni wis mĕsți,

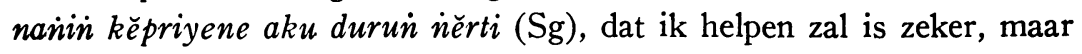
op welke manier (het hoe er van), dat weet ik nog niet. 


\section{E. Pir a}

Er behoeft na wat ik vroeger bij de behandeling van de telwoorden opgemerkt heb en na de bespreking van de categoriale formaties hierboven, niet veel meer over dit woord gezegd te worden. Slechts twee opmerkingen. In de eerste plaats is gebleken, dat er waarschijnlijk naast het numerale pira-pira ook een pronominaal pira-pira moet worden onderscheiden, al laat het tekort aan materiaal de beantwoording van de vraag of beide in het standaard Javaans voorkomen niet toe. In de tweede plaats moet nog vermeld worden de vorm pirane, hoeveel ervan, eveneens een duidelijk geval van transpositie naar de substantiva : wowohan sakrañjan iku pirane sin bosoq (Sg), van die mand vol vruchten, hoeveel er van is rot?.

\section{F. Kapan}

Kapan, historisch ongetwijfeld samenhangend met $a p a$, geeft geen aanleiding tot opmerkingen. Het heeft geen krama of madya equivalent. Als krama-term worden de groepen beñjii punapa en kala punapa gebruikt. Het in de woordenboeken vermelde kapanane, wanneer toch, was aan onze informanten niet bekend, en komt ook niet in de door ons gebruikte teksten voor. 